\title{
A New Mechanism of Receptor Targeting by Interaction between Two Classes of Ligand-Gated Ion Channels
}

\author{
Michel Boris Emerit, ${ }^{1,2}$ Camille Baranowski, ${ }^{1,2}$ Jorge Diaz, ${ }^{1,2}$ Audrey Martinez, ${ }^{3,4}$ Julie Areias, ${ }^{1,2}$ Jeanine Alterio, ${ }^{1,2}$ \\ Justine Masson, ${ }^{1,2}$ @Eric Boué-Grabot, ${ }^{3,4}$ and $₫$ Michèle Darmon ${ }^{1,2}$ \\ ${ }^{1}$ Centre de Psychiatrie et Neurosciences, INSERM UMR 894, 75013 Paris, France, ${ }^{2}$ Université Paris V, 75006 Paris, France, ${ }^{3}$ Institut des Maladies \\ Neurodégénératives, CNRS UMR 5293, 33076 Bordeaux, France, and ${ }^{4}$ Université de Bordeaux, 33076 Bordeaux, France
}

The 5- $\mathrm{HT}_{3}$ receptors are serotonin-gated ion channels that physically couple with purinergic $\mathrm{P} 2 \mathrm{X} 2$ receptors to trigger a functional cross-inhibition leading to reciprocal channel occlusion. Although this functional receptor-receptor coupling seems to serve a modulatory role on both channels, this might not be its main physiological purpose. Using primary cultures of rat hippocampal neurons as a quantitative model of polarized targeting, we show here a novel function for this interaction. In this model, 5- $\mathrm{HT}_{3 \mathrm{~A}}$ receptors did not exhibit by themselves the capability of distal targeting in dendrites and axons but required the presence of P2X2R for their proper subcellular localization. 5- $\mathrm{HT}_{3 \mathrm{~A}} \mathrm{R}$ distal targeting occurred with a delayed time course and exhibited a neuron phenotype dependency. In the subpopulation of neurons expressing endogenous $\mathrm{P} 2 \mathrm{X} 2 \mathrm{R}, 5-\mathrm{HT}_{3 \mathrm{~A}} \mathrm{R}$ distal neuritic localization correlated with P2X2R expression and could be selectively inhibited by P2X2R RNA interference. Cotransfection of both receptors revealed a specific colocalization, cotrafficking in common surface clusters, and the axonal rerouting of $5-\mathrm{HT}_{3 \mathrm{~A}} \mathrm{R}$. The physical association between the two receptors was dependent on the second intracellular loop of the 5- $\mathrm{HT}_{3 \mathrm{~A}}$ subunit, but not on the P2X2R C-terminal tail that triggers the functional cross-inhibition with the $5-\mathrm{HT}_{3 \mathrm{~A}} \mathrm{R}$. Together, these data establish that $5-\mathrm{HT}_{3 \mathrm{~A}} \mathrm{R}$ distal targeting in axons and dendrites primarily depends on $\mathrm{P} 2 \mathrm{X} 2 \mathrm{R}$ expression. Because several P2XR have now been shown to functionally interact with several other members of the 4-TMD family of receptor channels, we propose to reconsider the real functional role for this receptor family, as trafficking partner proteins dynamically involved in other receptors targeting.

Key words: 5- $\mathrm{HT}_{3}$ receptor; ligand-gated ion channels; $\mathrm{P} 2 \mathrm{X} 2$ receptor; receptor trafficking; receptor-receptor interactions; serotonin

Significance Statement

So far, receptor targeting mechanisms were found to involve intracellular partner proteins or supramolecular complexes that couple receptors to cytoskeletal elements and recruit them into cargo vesicles. In this paper, we describe a new trafficking mechanism for the neuronal serotonin $5-\mathrm{HT}_{3 \mathrm{~A}}$ ionotropic channel receptor, in which the role of routing partner is endowed by a functionally interacting purinergic receptor: the $\mathrm{P} 2 \mathrm{X} 2$ receptor. This work not only unveils the mechanism by which 5- $\mathrm{HT}_{3}$ receptors can reach their axonal localization required for the control of neurotransmitter release, but also suggests that, in addition to their modulatory role, the family of $\mathrm{P} 2 \mathrm{X}$ receptors could have a previously undescribed functional role of trafficking partner proteins dynamically involved in the targeting of other receptors.

\section{Introduction}

Receptor-receptor interactions have become an increasing field of investigations, unveiling a new level of complexity in receptor

Received June 22, 2015; revised 0ct. 28, 2015; accepted Nov. 20, 2015.

Author contributions: M.B.E. designed research;M.B.E., C.B., J.D., and J. Alterio performed research; M.B.E., A.M., E.B.-G., and M.D. contributed unpublished reagents/analytic tools; M.B.E., J. Areias, and J.M. analyzed data; M.B.E. wrote the paper.

This work was supported by INSERM and University Paris Descartes. Confocal imaging was performed at the Plateforme Imagerie Cellulaire PICPEN (Centre de Psychiatrie et Neurosciences). C.B. received fellowships from INSERM during performance of this work. We thank Dr. Connolly (University of Dundee, Dundee, Scotland) for providing the plasmid encoding the human $\mathrm{HA}-\mathrm{h} 5-\mathrm{HT}_{3 \mathrm{~A}}$ subunit, Dr. Rassendren (CNRS UMR 5203, Université de regulation. However, recent studies suggest that such interactions might go beyond classical functional cross talk mechanisms and extend to the modulation of receptor trafficking, surface expression, and positioning within the plasma membrane (Jo et al., 2011; Shrivastava et al., 2011; Pougnet et al., 2014). 5- $\mathrm{HT}_{3}$ and

Montpellier, Montpellier, France) for providing the plasmid encoding the P2X2b-YFP variant, and Dr. Jacques Laschet (INSERM U1129) for performing the statistical analyses.

The authors declare no competing financial interests.

Correspondence should be addressed to Dr. Michel Boris Emerit, INSERM U894, 2ter rue d'Alésia, 75014 Paris, France. E-mail: michel-boris.emerit@inserm.fr.

DOI:10.1523/JNEUROSCI.2390-15.2016

Copyright $\odot 2016$ the authors $\quad 0270-6474 / 16 / 361456-15 \$ 15.00 / 0$ 
$\mathrm{P} 2 \mathrm{X} 2$ receptors are two functionally interacting receptors belonging to two different classes of ligand-gated ion channels, of the three major classes present in mammals: the cys-loop receptors, the ionotropic $\mathrm{P} 2 \mathrm{X}$ receptors, and the glutamate receptors (Collingridge et al., 2009). 5- $\mathrm{HT}_{3}$ receptors are serotonin-gated channels mediating fast excitatory transmission in the CNS and periphery (Sugita et al., 1992) and neurotransmitter release (van Hooft and Vijverberg, 2000). Since the cloning of the canonical $5-\mathrm{HT}_{3 \mathrm{~A}}$ homomeric form (Maricq et al., 1991), their diversity of functions has found a molecular basis with the discovery of additional subunits (Davies et al., 1999; Niesler et al., 2003) that coassemble with the 3A subunit to modulate their electrophysiological properties (Davies et al., 1999; Jensen et al., 2008; Holbrook et al., 2009). In the CNS, $5-\mathrm{HT}_{3}$ receptors are mainly neuronal and are present both postynaptically on GABAergic hippocampal and cortical interneurons (Tecott et al., 1993; Lee et al., 2010; Vucurovic et al., 2010) and presynaptically on nerve terminals projecting from various peripheral ganglia (Miquel et al., 2002; Morales and Wang, 2002; Doucet et al., 2007), but their role in peripheral functions is also widespread, particularly in the intestinal tract (Glatzle et al., 2002; Holbrook et al., 2009). $5-\mathrm{HT}_{3 \mathrm{~A}}$ subunits have been found to depend on the protein RIC-3 for their surface targeting in clonal cells (Castillo et al., 2005; Cheng et al., 2005; Walstab et al., 2010). However, RIC-3 appears to act as a chaperone protein mainly involved in proper receptor folding, common to $5-\mathrm{HT}_{3 \mathrm{~A}}$ and nicotinic receptors (Castillo et al., 2005; Alexander et al., 2010), and no data confirm so far a relevant role of RIC-3 in 5- $\mathrm{HT}_{3}$ trafficking within neurons. Thus, the molecular mechanisms of $5-\mathrm{HT}_{3}$ receptor targeting in neurons remain largely unknown.

P2X2 receptors are one subtype of the seven known P2X receptors that can all form homomeric or heteromeric ATP-gated channels widely distributed in CNS and periphery (Saul et al., 2013). In the periphery, $\mathrm{P} 2 \mathrm{X} 2$ mediate fast synaptic transmission in the myenteric plexus (Ren et al., 2003) and were originally expected to have a similar function in the brain. However, reports of ATP-mediated fast synaptic transmission in the brain are scarce, suggesting that $\mathrm{P} 2 \mathrm{X} 2$ rather play a neuromodulatory role at central synapses (Khakh and North, 2012). Indeed, because P2X2 localize mainly in the periphery of excitatory glutamatergic synapses and seem excluded from the postsynaptic density (Rubio and Soto, 2001; Richler et al., 2011), and because they are present on the terminals of ganglionic (Vulchanova et al., 1996) and hippocampal (Khakh et al., 2003) neurons, other functional roles for these receptors were assumed (Khakh et al., 2003; Vavra et al., 2011; Khakh and North, 2012).

P2X2 receptors have been found to interact physically and functionally with several other receptors and ion channels, including nicotinic (Barajas-López et al., 1998; Khakh et al., 2000; Khakh et al., 2005), GABA (Boué-Grabot et al., 2004b) GABA $_{\mathrm{A}}$ (Boué-Grabot et al., 2004a), and 5- $\mathrm{HT}_{3}$ receptors (Barajas-López et al., 2002; BouéGrabot et al., 2003). These subunit-specific interactions result in a cross-inhibition induced by reciprocal channel occlusion that involves direct protein-protein contact (Boué-Grabot et al., 2003; Khakh et al., 2005). However, more recent work has found that P2X receptors could also influence $\mathrm{GABA}_{\mathrm{A}}$ receptor dynamics (Jo et al., 2011; Shrivastava et al., 2011) and surface expression of AMPA receptors (Pougnet et al., 2014), opening new insights into P2X receptor functionality. In this study, we have addressed a completely new functional role for $\mathrm{P} 2 \mathrm{X} 2$ receptors, as trafficking partners for the axonal and dendritic localizations of $5-\mathrm{HT}_{3}$ receptors in hippocampal neurons.

\section{Materials and Methods}

Animals

Female gestating Sprague Dawley rats (Charles River Breeding Center) were maintained under controlled environmental conditions $\left(21 \pm 1^{\circ} \mathrm{C}\right.$, $60 \%$ relative humidity, $12 \mathrm{~h} / 12 \mathrm{~h}$ light/dark cycle), with food and water available ad libitum until killed for embryo removal. Experiments were performed in agreement with the institutional guidelines for use of animals and their care, in compliance with national and international laws and policies (Council directives no. 87-848, October 19, 1987, Ministère de l'Agriculture et de la Forêt, Service Vétérinaire de la Santé et de la Protection Animale, permissions nos. 75-976 to M.B.E., 75-805 to J.M., 75-974 to M.D.).

\section{Antibodies}

The following primary antibodies were used: mouse monoclonal anti-HA antibody (Sigma; 1:1000), rabbit anti-HA antibody (Sigma, Abcam, Cell Signaling Technology, 1:1000), mouse monoclonal antiFlag M2 antibody (Sigma, 1:2000), mouse monoclonal anti-myc (Roche, 1:500), rabbit anti-myc (Millipore, 1:500), mouse anti-GFP antibody (GE Healthcare, 1:1000), rabbit anti-GFP antibody (Millipore Bioscience Research Reagents, 1:1000), mouse monoclonal anti- $\alpha$-tubulin antibody (Abcam, 1:2000), rabbit anti-tubulin antibody (Novus Biologicals, 1:1000), rabbit anti-MAP2 antibody (Millipore Bioscience Research Reagents, 1:1000), rabbit anti-P2X2R antibody (Alomone Labs, 1:300), guinea pig anti-P2X2R antibody (Millipore, 1:300), mouse monoclonal anti-dsRed antibody (Clontech, 1:1000), rabbit anti-5- $\mathrm{HT}_{3 \mathrm{~A}}$ antibody (1:1000) (Doucet et al., 2000), and goat anti-5-HT $3 \mathrm{~B}$ antibody (1:1000) (Doucet et al., 2007). The secondary antibodies used were AlexaFluor488 and -594-conjugated antibodies from Invitrogen (1:1000) and HRPconjugated anti-rabbit and anti-mouse antibodies (Sigma, 1:10,000).

\section{Plasmid constructs and site-directed mutagenesis}

$5-\mathrm{HT}_{3 \mathrm{~A}}-\mathrm{HA}$ was generated from a $\mathrm{pRC}-\mathrm{CMV}$ plasmid described previously (Emerit et al., 2002) by extraction of the mouse $5-\mathrm{HT}_{3 \mathrm{~A}}$ sequence with HindIII and BamHI and insertion into the pcDNA3 vector (Invitrogen) between the HindII and EcoRI sites in two steps, with a cassette containing the HA epitope (YPYDVPDYA) separated by a Gly3 arm in C-terminal position before the stop codon. The human HA-tagged $5-\mathrm{HT}_{3 \mathrm{~A}}$ subunit (HA tag inserted between amino acids 5 and 6), subcloned into the pGW1 plasmid (Boyd et al., 2003), was a generous gift of Dr. C. N. Connolly (Ninewells Medical School, University of Dundee, Dundee, Scotland). The mouse $5-\mathrm{HT}_{3 \mathrm{~A}}$-Flag plasmid was previously described (Emerit et al., 2002). The plasmids encoding rat 5- $\mathrm{HT}_{1 \mathrm{~A}}-\mathrm{eGFP}$ (Carrel et al., 2008), sst2A-eGFP (Lelouvier et al., 2008), P2X2-YFP (Boué-Grabot et al., 2003), P2X2b-YFP (Koshimizu et al., 2006), YFP-5$\mathrm{HT}_{3 \mathrm{~A}}$ (Grailhe et al., 2004), and P2X4-FlagIN (Jo et al., 2011) have already been used and described. P2X2, P2X2Tr, P2X3-Flag, P2X3-YFP, myc- $\rho 1$ subcloned into pcDNA3, myc-tagged GluA1, or GluA2 subcloned into PrK5 vector were described previously (Boué-Grabot et al., 2000; 2004a; Pougnet et al., 2014). Myc-NR2A was a gift from L. Groc (Interdisciplinary Institute for Neuroscience, Bordeaux, France). HAtagged P2X2 and P2X2Tr were generated by insertion of a sequence encoding the YPYDVPDYA epitope between amino acids D78 and K79 within the extracellular domain of P2X2 subunits using the QuikChange site-directed mutagenesis method (Agilent) with specific oligonucleotides. P2X2Tr corresponded to a deletion of the 98 last amino acids of the C-terminal domain of P2X2 (Boué-Grabot et al., 2000). HA-tagged $\mathrm{P} 2 \mathrm{X} 2 \Delta \mathrm{C} 36$ or $\mathrm{P} 2 \mathrm{X} 2 \Delta \mathrm{C} 57$ was generated by insertion of a stop codon into the sequence of HA-P2X2 using the QuikChange mutagenesis method at specific position to delete the 36 or 57 last amino acids of HA-P2X2, respectively. $5-\mathrm{HT}_{3 \mathrm{~A}}-\mathrm{IL} 2 \beta 3-\mathrm{HA}$ and $5-\mathrm{HT}_{3 \mathrm{~A}}-\mathrm{IL} 2 \gamma 2-\mathrm{HA}$ chimeras were generated by substitution of the second intracellular loop (IL2) of the $5-\mathrm{HT}_{3 \mathrm{~A}}$ subunit with the homologous domain of $\mathrm{GABA}_{\mathrm{A}} \beta 3$ or $\gamma 2$ subunit, respectively, using the QuikChange method and megaprimer strategy. The sequences corresponding to the IL2 of $\beta 3$ or $\gamma 2$ subunits were first amplified by PCR from $\beta 3$ or $\gamma 2$ constructs using pfu polymerase (Fermentas) and primers with flanking regions corresponding to adjacent $5-\mathrm{HT}_{3 \mathrm{~A}}$ sequences. Each PCR product was then used as megaprimers on $5-\mathrm{HT}_{3 \mathrm{~A}}-\mathrm{HA}$ plasmid to generate by the QuikChange method 
5- $\mathrm{HT}_{3 \mathrm{~A}}$-IL2 $33-\mathrm{HA}$ and 5- $\mathrm{HT}_{3 \mathrm{~A}}-\mathrm{IL} 2 \gamma 2-\mathrm{HA}$. All constructs were verified by sequencing.

\section{Xenopus oocyte electrophysiology}

Oocytes were removed from Xenopus laevis as previously described (Jo et al., 2011). The amount of cDNA for wild-type or mutated subunits was adjusted to reach similar levels of expression and avoid overexpression. After nuclear injection of cDNAs coding for wild-type or deleted HAP2X2 (30 pg) as well as wild-type or chimeric HA-5- $\mathrm{HT}_{3}$ subunits (100$300 \mathrm{pg}$ ), oocytes were incubated in Barth's solution containing $1.8 \mathrm{~mm}$ $\mathrm{CaCl}_{2}$ and gentamycin $(10 \mathrm{mg} / \mathrm{ml}$, Sigma $)$ at $19^{\circ} \mathrm{C}$ for $1-3 \mathrm{~d}$ before electrophysiological recordings were performed as previously described (Pougnet et al., 2014). Two-electrode voltage-clamp recordings were performed at room temperature using glass pipettes $(1-2 \mathrm{M} \Omega)$ filled with $3 \mathrm{M} \mathrm{KCl}$ solution to ensure a reliable holding potential. Oocytes were voltage-clamped at $-60 \mathrm{mV}$, and the membrane currents were recorded with an OC-725B amplifier (Warner Instruments) and digitized at $1 \mathrm{kHz}$ on a Power PC Macintosh G4 using Axograph X software (Axograph). Oocytes were perfused at a flow rate of $10-12 \mathrm{ml} / \mathrm{min}$ with Ringer's solution, $\mathrm{pH}$ 7.4, containing the following (in mM): $115 \mathrm{NaCl}, 3 \mathrm{NaOH}, 2$ $\mathrm{KCl}, 1.8 \mathrm{CaCl}_{2}$, and $10 \mathrm{HEPES}$. Agonists were prepared at their final concentrations in the perfusion solution and applied using a computerdriven valve system (Ala Scientific).

\section{Neuronal cultures}

Neuronal cultures were made as described previously (Carrel et al., 2008) with some modifications. Hippocampi of rat embryos were dissected at day 18. After trypsinization, tissue dissociation was achieved with a Pasteur pipette. Cells were counted and plated on poly-D-lysine-coated 15mm-diameter coverslips (Electron Microscopy Sciences), at a density of 200-300 cells per square millimeter, in complete Neurobasal medium supplemented with B27 (Invitrogen), containing 0.5 mM GlutaMAXI, 10 $\mathrm{U} / \mathrm{ml}$ penicillin $\mathrm{G}$, and $10 \mathrm{mg} / \mathrm{ml}$ streptomycin. Three hours after plating, the medium was replaced by a conditioned medium obtained by incubating glial cultures ( $70 \%-80 \%$ confluency) for $24 \mathrm{~h}$ in the complete medium described above.

Glial cultures were prepared as follows: cortex of 4-d-old rat pups was dissected and fragmented into smaller pieces through a pipette. After trypsinization, tissue dissociation was achieved with a pasteur pipette. After several washes, the cells were plated into $150 \mathrm{~cm}^{2}$ tissue culture flasks in DMEM GlutaMAXI (Invitrogen) supplemented with $1 \mathrm{~g} / \mathrm{L}$ glucose, $10 \% \mathrm{FBS}, 10 \mathrm{U} / \mathrm{ml}$ penicillin $\mathrm{G}$, and $10 \mathrm{~g} / \mathrm{ml}$ streptomycin. This primary culture was expanded every $7-10 \mathrm{~d}$, and cultures between the first and the fourth passage were used to prepare the conditioned medium described above.

\section{Transfection of neuronal cultures}

Hippocampal neurons were transfected at $4-5$ to 15 DIV as follows: for each coverslip, plasmid DNA $(2.5 \mu \mathrm{g})$ was mixed with $50 \mu \mathrm{l}$ of Neurobasal medium without B27 supplement. After $15 \mathrm{~min}$ at room temperature, $1.25 \mu \mathrm{l}$ of Lipofectamine 2000 (Invitrogen) in $50 \mu \mathrm{l}$ of Neurobasal medium was added, and incubation continued for another $30 \mathrm{~min}$. After the addition of $150 \mu \mathrm{l}$ of complete Neurobasal medium containing B27 supplement, the mix was applied onto the neuronal culture, and transfection lasted for $3 \mathrm{~h}$ at $37^{\circ} \mathrm{C}$. After transfection, the medium in which the neurons were grown was put back on to the neurons for the expression period (usually $48 \mathrm{~h}$ ). Typically, $5 \%-10 \%$ of neurons expressed the receptors after transfection.

\section{Inhibition of receptor expression}

For silencing endogenous P2X2R expression, we tested three different siRNAs (Sigma, Invitrogen, and Thermo Scientific) directed against the rat subunit: siRNA(P2X2)-1 (ACCUGCCAUUCAGACGACGACU GUA), siRNA(P2X2)-2 (CAUCUUCAGGCUGGGUUUCAUUGUU), siRNA(P2X2)-3 (CACCAUCAUCAAUCUGGCCACUGCU), and control siRNA (CCAGUACUUCGUACUCCAAUCGACA) (Carrel et al., 2008). An optimal protocol for the simultaneous inhibition of endogenous $\mathrm{P} 2 \mathrm{X} 2 \mathrm{R}$ expression and $5-\mathrm{HT}_{3 \mathrm{~A}} \mathrm{R}$ expression at $7 \mathrm{DIV}$ was set as follows: for each coverslip, plasmid DNA $(2.5 \mu \mathrm{g})$ was mixed with $25 \mu \mathrm{l}$ of Neurobasal medium without B27 supplement. After $15 \mathrm{~min}$ at room temperature, $0.5 \mu \mathrm{l}$ of Lipofectamine 2000 (Invitrogen) in $25 \mu \mathrm{l}$ of Neurobasal medium was added, and incubation continued for another 30 min. Simultaneously and separately, $2 \mu$ l of siRNA ( $160 \mathrm{~nm}$ final concentration) was mixed with $25 \mu \mathrm{l}$ of Neurobasal medium without B27 supplement. After $15 \mathrm{~min}$ at room temperature, $0.5 \mu \mathrm{l}$ of RNAiMAX (Invitrogen) in $25 \mu$ l of Neurobasal medium was added, and incubation continued for another $30 \mathrm{~min}$. Plasmid and RNA complexes were mixed, and $150 \mu \mathrm{l}$ of complete Neurobasal medium containing B27 supplement was added. The mix was then applied onto the neuronal culture, and transfection lasted for $3 \mathrm{~h}$ at $37^{\circ} \mathrm{C}$. After transfection, the medium in which the neurons were grown was put back on to the neurons for the expression period (usually $48-72 \mathrm{~h}$ ). Optimal results were obtained with siRNA(P2X2)-3.

\section{Immunofluorescence}

Cells on coverslips were washed with $\mathrm{DPBS}^{+}$(DPBS containing $0.1 \mathrm{~mm}$ $\mathrm{CaCl}_{2}$ and $0.1 \mathrm{~mm} \mathrm{MgCl}_{2}$ ) at $37^{\circ} \mathrm{C}$, then fixed with $3 \%$ PFA containing $4 \%$ sucrose (PFA/sucrose) at $37^{\circ} \mathrm{C}$ in $\mathrm{DPBS}^{+}$, and permeabilized with $0.1 \%$ Triton X-100 in DPBS (without $\mathrm{CaCl}_{2}, \mathrm{MgCl}_{2}$ ). After two washes (10 min) in DPBS, cells were incubated for $30 \mathrm{~min}$ in antibody buffer $(3 \%$ BSA, $2 \%$ normal donkey serum, $2 \%$ normal goat serum, except when using goat primary antibodies, in DPBS). Incubation with primary antibodies was then performed in antibody buffer at room temperature $(1 \mathrm{~h})$. After two washes in DPBS, incubation with secondary antibodies proceeded for $1 \mathrm{~h}$. The coverslips were finally mounted in Fluoromount-G solution (Clinisciences) for immunofluorescence visualization using confocal microscopy.

\section{Microscopy}

Immunofluorescence images were generated using a Leica TCS SP5 AOBS laser scanning confocal microscope $(25,40,63$, or $100 \times$ oilimmersion lenses). Contrast and brightness were chosen to ensure that all pixels were within the linear range. Images were the product of 12-fold line averages. In all cases, emission and excitation filters proper to each fluorophore were used sequentially, and the absence of cross talk between different channels was checked with selectively labeled preparations. Leica pictures (.lei) were saved as Tiff images, and plates were assembled using Adobe Photoshop CS2 (Adobe Systems). Background was lowered using Gaussian blur (radius 1 pixel), and contrast and brightness of images displayed in figures were modified using Adobe Photoshop CS2 only for illustrations.

\section{Quantification of dendrite fluorescence}

Fluorescence profiles along dendrites and axons were generated using the Lucia 4.71 software (Nikon). For fluorescence profile comparisons, all neurons showing intact morphology with unambiguous visual identification of the axon were analyzed (one dendrite or axon per neuron). The variability of distribution in individual neurons was eliminated by using the cumulated fluorescence profiles obtained for 20-40 neurons in each group (Carrel et al., 2008). Usually, quantitative data were generated by extracting the area under each individual curve between the soma and $50-100 \mu \mathrm{m}$ for the totality of neurons analyzed and then normalized to the mean value of the control condition. Data analysis was performed with Prism software (GraphPad). All results are reported as mean \pm SEM. Statistical significance was assessed by using Student's $t$ test or one-way or two-way ANOVA with Bonferroni's or Dunnett's post hoc tests. The level of significance was set at $p<0.05$.

\section{Colocalization analysis}

Receptor-receptor colocalization was measured by using the JACoP plugin of FIJI (ImageJ) software (Bolte and Cordelières, 2006). The manual threshold method was adapted to the quantification of fluorescence overlap onto the clustered components of receptor distributions within the dendritic trees. ROI were chosen to avoid the cell bodies and the intense intracellular fluorescence found in the center of the larger dendrites. The threshold was chosen in each case to select the clustered component of receptor distribution and to avoid inclusion of the diffuse component that could lead to random overlap noise. Mander's M1 coefficients (representing the proportions of clustered $5-\mathrm{HT}_{3 \mathrm{~A}}$ receptors 

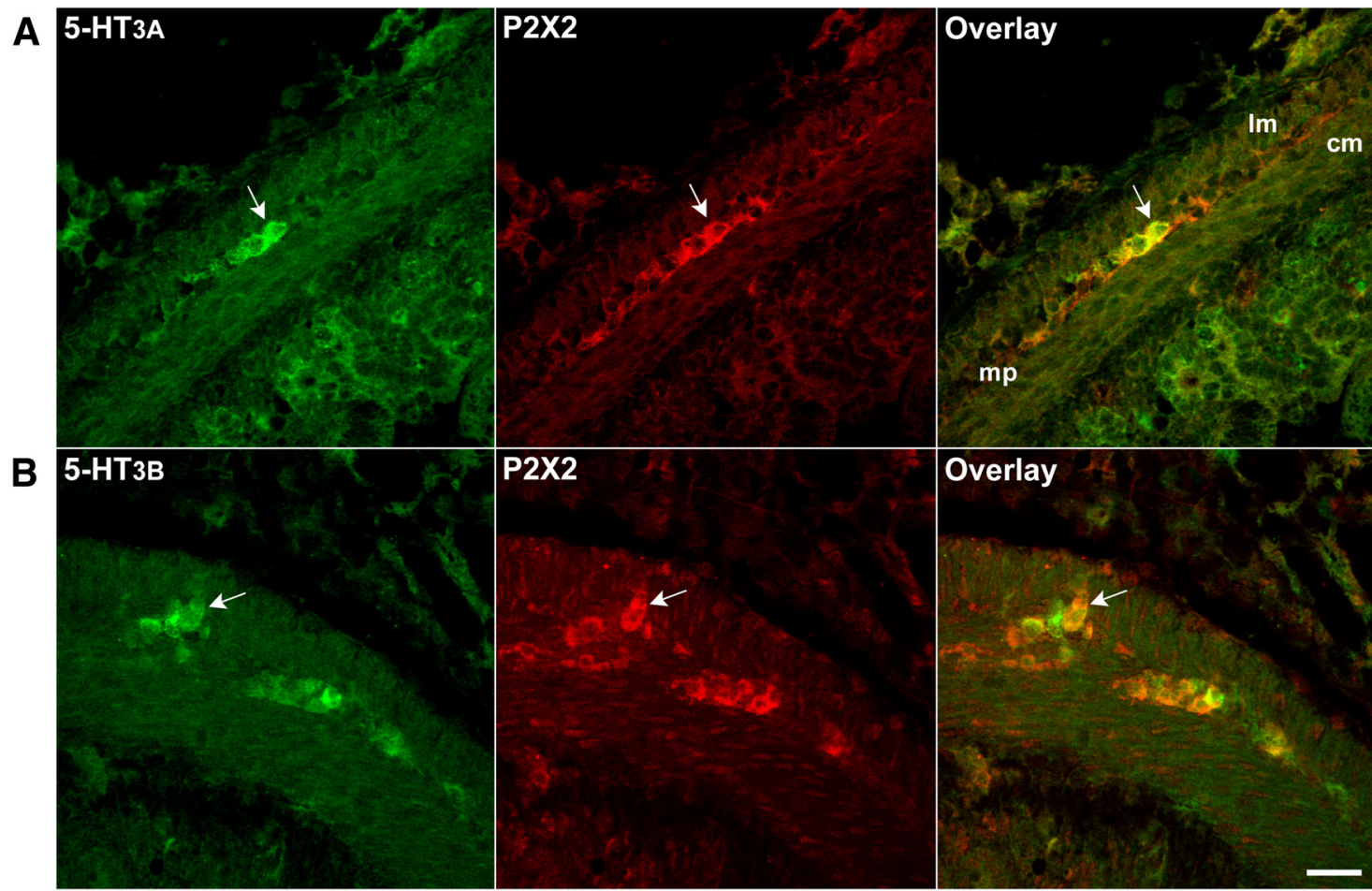

Figure 1. $5-\mathrm{HT}_{3}$ and $\mathrm{P} 2 \mathrm{X} 2$ receptors are coexpressed in neurons of the myenteric plexus. Immunohistochemical detection of $5-\mathrm{HT}_{3 \mathrm{~A}}, 5-\mathrm{HT}_{3 \mathrm{~B}}$, and $\mathrm{P} 2 \mathrm{X} 2$ subunits in the rat intestinal tract at $4 \mathrm{~d}$ postnatal. $A, 5-\mathrm{HT}_{3 \mathrm{~A}}$ (rabbit anti-5- $\mathrm{HT}_{3 \mathrm{~A}}$ antibody; green) and $\mathrm{P} 2 \mathrm{X} 2$ (guinea pig anti-P2X2 antibody; red). $B, 5-\mathrm{HT}_{3 \mathrm{~B}}$ (goat anti 5- $\mathrm{HT}_{3 \mathrm{~B}}$ antibody; green) and $\mathrm{P} 2 \mathrm{X} 2$ (rabbit anti- $\mathrm{P} 2 \mathrm{X} 2$ antibody; red). Both 5- $\mathrm{HT}_{3}$ subunits colocalize with P2X2R in the same neurons (arrows). mp, Myenteric plexus; Im, longitudinal muscle; $\mathrm{cm}$, circular muscle. Scale bar, $50 \mu \mathrm{m}$.

colocalized with clustered cotransfected receptors) were then used as the relevant parameters on which the statistical analyses were performed.

\section{Immunohistochemistry}

Tissue preparation. Rat pups (postnatal life 1 week) and adult mice were killed by decapitation. The brain of mice was rapidly removed and immediately frozen by immersion in isopentane cooled by dry ice $\left(-40^{\circ} \mathrm{C}\right)$. The whole body of rat pups was also frozen by immersion in isopentane cooled by dry ice $\left(-40^{\circ} \mathrm{C}\right)$. The frozen rat pups and brains of mice were conserved at $-75^{\circ} \mathrm{C}$ until cryostat sectioning. Sagittal sections of whole body of pups and coronal sections of brains ( $12 \mu \mathrm{m}$ thick) were prepared on a cryostat (JUNG3000, Leica), thawmounted onto slides SuperFrost-Plus (Menzel-Glaser), and kept at $-75^{\circ} \mathrm{C}$ until use for immunohistochemistry.

Immunohistochemistry: double immunofluorescent staining for $5-\mathrm{HT}_{3}$ and $\mathrm{P} 2 \mathrm{X} 2$ receptors. Frozen sections were thawed to $4^{\circ} \mathrm{C}$ and fixed during 10 min with $2 \%$ PFA made up in $0.1 \mathrm{M} \mathrm{PB}, \mathrm{pH} 7.4$ at $4^{\circ} \mathrm{C}$ or fixed with methanol at $-20^{\circ} \mathrm{C}$ for $15 \mathrm{~min}$. After washing three times for 5 min each with $50 \mathrm{~mm}$ PBS, the sections were immersed in $50 \mathrm{~mm}$ Tris-buffered saline, pH 7.5 (TBS) and then blocked with the blocking buffer $(10 \%$ normal donkey serum, $0.1 \%$ BSA, $0.1 \%$ gelatin, $0.1 \%$ Tween 20 , and $0.1 \%$ Triton $\mathrm{X}-100$ in TBS) for $1 \mathrm{~h}$ at $37^{\circ} \mathrm{C}$. Sections were then incubated with the primary antibodies: rabbit anti-5- $\mathrm{HT}_{3 \mathrm{~A}}$ (1:500 dilution) and guinea-pig anti-P2X2 (Millipore, 1:500 dilution) or goat anti-5- $\mathrm{HT}_{3 \mathrm{~B}}$ and rabbit anti-P2X2 (Alomone, 1:500 dilution) in dilution buffer (50 mM TBS, pH 7.6; 0.1\% BSA; $0.1 \%$ gelatin, $0.1 \%$ Tween 20 , and $0.05 \%$ Triton X-100) overnight at $4^{\circ} \mathrm{C}$. After washing three times with TBS $(0.1 \%$ gelatin; $0.1 \%$ Tween 20$)$, sections were incubated with the following secondary antibodies (Alexa488-donkey anti-rabbit and Cy3-donkey anti-guinea-pig or Alexa488-donkey anti-goat and Cy3-donkey antirabbit (Jackson ImmunoResearch Laboratories, 1:500 dilution for each) in dilution buffer TBS $(0.1 \%$ Tween 20$)$ for $1 \mathrm{~h}$ at room temperature. After three rinses with TBS-Tween 20, sections were coverslipped with Fluoromount-G mounting media (Southern Biotechnology).

Statistical analyses

Distributions of data were analyzed for normality (simple or bimodal). Data are presented as mean \pm SEM. Statistical significance was assessed using linear regression, $t$ test, one-way or two-way ANOVA followed by Dunnett or Bonferroni's tests. Critical level of significance was set at $p \leq$ 0.05 . Analyses were performed using JMP V.10 (SAS Institute) and GraphPad software.

\section{Results}

Native $5-\mathrm{HT}_{3}$ and $\mathrm{P} 2 \mathrm{X} 2$ receptors are coexpressed within the same neurons

If $5-\mathrm{HT}_{3}$ and $\mathrm{P} 2 \mathrm{X} 2$ receptors undergo a common fate within a supramolecular partnership, then they should share an overlapping distribution and be expressed within the same neurons. $5-\mathrm{HT}_{3} \mathrm{R}$ tissue distributions are well documented by in situ hybridization (Tecott et al., 1993; Morales and Wang, 2002), radioligand binding (Laporte et al., 1992), and antibody labeling (Doucet et al., 2000; Miquel et al., 2002). In the CNS, 5- $\mathrm{HT}_{3} \mathrm{R}$ are present in scattered neurons in the cortex (Tecott et al., 1993; Lee et al., 2010), in hippocampus CA1 and CA3 layers, amygdala, nucleus of the solitary tract, Sp5, and dorsal horns of the spinal cord (Laporte et al., 1992; Doucet et al., 2000). In the periphery, $5-\mathrm{HT}_{3} \mathrm{R}$ are mainly represented in several peripheral ganglia (Morales and Wang, 2002; Doucet et al., 2007) and in the intestinal tract, in neurons of the myenteric and submucosal plexus (Glatzle et al., 2002). P2X2R share a tissue distribution that is remarkably overlapping with $5-\mathrm{HT}_{3} \mathrm{R}$ albeit wider, including many non-neuronal cell types (for an extensive review, see North, 2002). However, colocalization within the same neurons has only been described by electrophysiological recordings (BarajasLópez et al., 2002; Boué-Grabot et al., 2003) and remained to be demonstrated by immunocytological methods. We have used previously described antibodies against the $5-\mathrm{HT}_{3 \mathrm{~A}}$ (Doucet et al., 2000) and the 5- $\mathrm{HT}_{3 \mathrm{~B}}$ (Doucet et al., 2007) subunits to illustrate such a coexpression of native $5-\mathrm{HT}_{3}$ and $\mathrm{P} 2 \mathrm{X} 2$ receptors in neurons of the rat myenteric plexus using two independent couples of antibodies: rabbit anti-5- $\mathrm{HT}_{3 \mathrm{~A}}$ and guinea pig anti-P2X2 


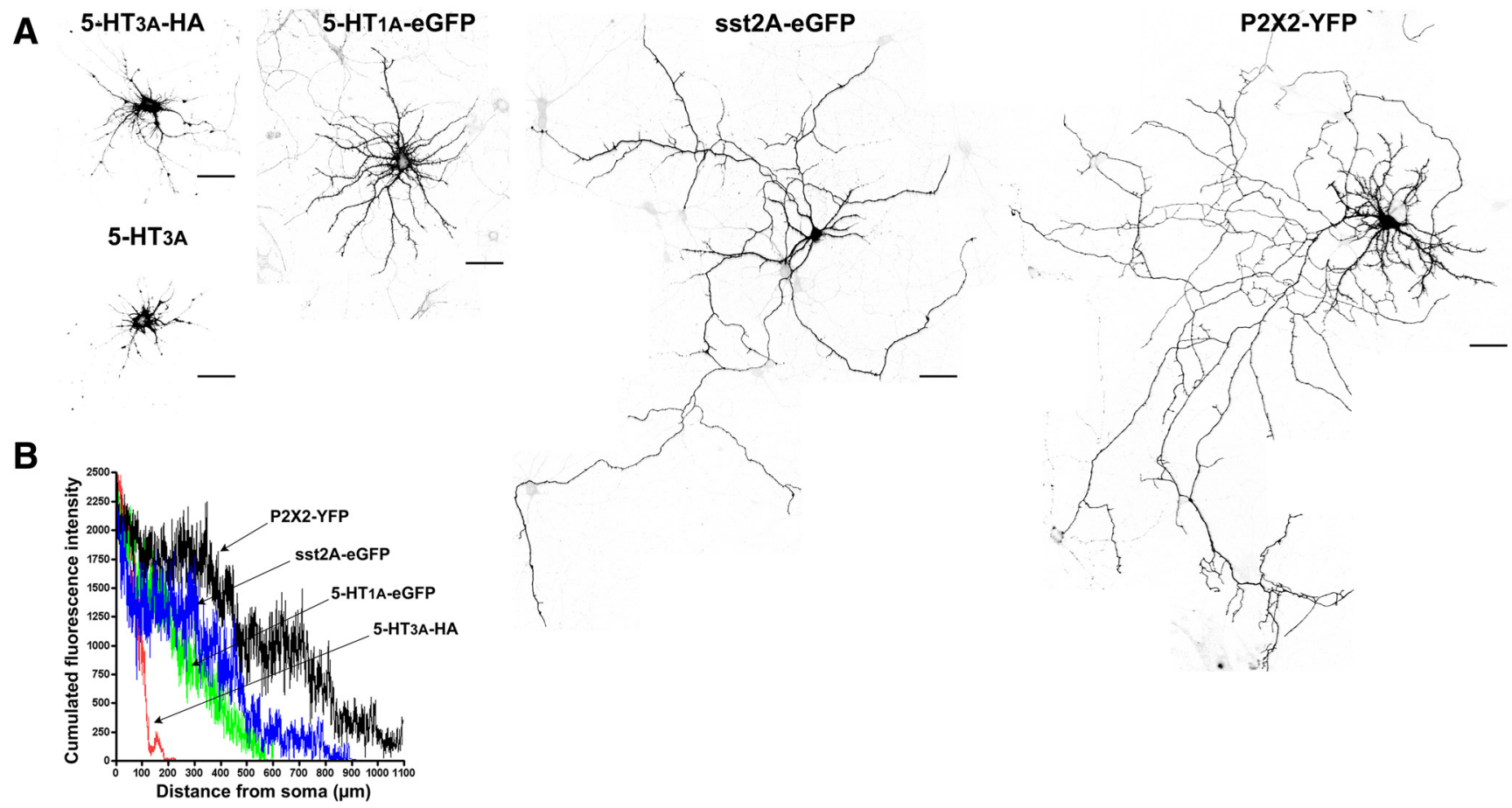

Figure 2. The majority of hippocampal neurons in culture do not address $5-\mathrm{HT}_{3 \mathrm{~A}}$ receptors distally. Hippocampal neurons were transfected at $7 \mathrm{DIV}$ with $5-\mathrm{HT} \mathrm{HA}_{3 \mathrm{~A}}-\mathrm{HA}$, untagged $5-\mathrm{HT}_{3 \mathrm{~A}^{\prime}}$ 5-HT 1 AA $^{-}$-GFP, sst2A-eGFP, or P2X2-YFP subunits. $\boldsymbol{A}$, Immunofluorescence was performed with anti-HA, anti-5- $\mathrm{HT}_{3 \mathrm{~A}}$ or anti-GFP antibodies (to enhance GFP and YFP signals). $\boldsymbol{B}$, Cumulated fluorescence intensities along the longest neurite were plotted for a representative sample of 10 neurons from each transfected culture. Whereas $70 \%$ of $5-\mathrm{HT}_{3 \mathrm{~A}} \mathrm{R}$ expressing neurons did not address the receptor distally in neurites, nearly $100 \%$ of transfected neurons addressed $5-\mathrm{HT}_{1 \mathrm{~A}} \mathrm{R}$ in the entire dendritic tree and nearly $100 \%$ of neurons addressed sst $2 \mathrm{AR}$ and P2X2R in the entire dendritic and axonal arborizations. Scale bar, $50 \mu \mathrm{m}$.

(Millipore) (Fig. 1A) and goat anti-5- $\mathrm{HT}_{3 \mathrm{~B}}$ and rabbit anti-P2X2 (Alomone Labs) (Fig. 1B). In both cases, labeling was found within the same cell bodies (Fig. 1, arrows) of neurons of the myenteric and submucosal plexus and occasionally on fibers crossing the longitudinal and circular muscles.

\section{Delayed onset of 5- $\mathrm{HT}_{3 \mathrm{~A}}$ receptor trafficking in a} subpopulation of cultured hippocampal neurons We used primary cultures of hippocampal neurons to challenge a functional partnership between $5-\mathrm{HT}_{3 \mathrm{~A}}$ homomeric and $\mathrm{P} 2 \mathrm{X} 2$ receptors in regards to polarized trafficking. This model has proven to be fully adapted to the quantification of dendritic or axonal targeting of various receptors (Carrel et al., 2008, 2011; Al Awabdh et al., 2012). Because 5- $\mathrm{HT}_{3} \mathrm{R}$, although present in these cultures, are expressed at levels too low to be detected by specific antibodies, we used transfected tagged $5-\mathrm{HT}_{3 \mathrm{~A}}$ subunits. We first tested various tags and their position within the $5-\mathrm{HT}_{3}$ sequence and compared them with $5-\mathrm{HT}_{3 \mathrm{~A}} \mathrm{Wt}$ (labeled with anti-5- $\mathrm{HT}_{3 \mathrm{~A}}$ antibodies) to make sure that the tag itself did not interfere with trafficking mechanisms. 5- $\mathrm{HT}_{3 \mathrm{~A}}$-GFP (GFP tag in C-terminal position) and YFP-5- $\mathrm{HT}_{3 \mathrm{~A}}$ (YFP in the $\mathrm{N}$-extracellullar domain after a signal peptide from the glycine receptor) (Grailhe et al., 2004) did not exhibit a subcellular distribution identical to $5-\mathrm{HT}_{3 \mathrm{~A}} \mathrm{Wt}$, the first one being retained within the endoplasmic reticulum, and the second one fully filling the dendritic tree in all transfected neurons. Instead, all tagged $5-\mathrm{HT}_{3 \mathrm{~A}} \mathrm{R}$ carrying a small tag on the extracellular $\mathrm{C}$-tail exhibited a distribution that was indistinguishable from $5-\mathrm{HT}_{3 \mathrm{~A}} \mathrm{Wt}$ (Fig. $2 \mathrm{~A}$ ). We then compared the expression of $5-\mathrm{HT}_{3 \mathrm{~A}}-\mathrm{HA}$ homomeric receptors with the ones of a dendritic receptor, the $5-\mathrm{HT}_{1 \mathrm{~A}}$-eGFP (Carrel et al., 2008), and two dendritic/axonal receptors: sst2A-eGFP (Lelouvier et al., 2008) and P2X2-YFP (Bobanovic et al., 2002). In iden- tical conditions (same culture, transfection parameters, and expression time), $5-\mathrm{HT}_{3 \mathrm{~A}}-\mathrm{HA}$ subunits appeared to be restricted to the proximal part of dendrites (Fig. $2 A$ ), whereas $5-\mathrm{HT}_{1 \mathrm{~A}}$ eGFP receptors filled the entire dendritic tree and sst2A-eGFP or $\mathrm{P} 2 \mathrm{X} 2$-YFP receptors filled both the entire dendritic and axonal networks, with a homogeneous distribution in almost $100 \%$ of neurons. Figure $2 B$ shows cumulated fluorescence curves along the longest neurite for a sample of neurons expressing $5-\mathrm{HT}_{3 \mathrm{~A}}-\mathrm{HA}$ subunits in proximal dendrites only, and compares them with 5-HT $\mathrm{HA}_{\mathrm{A}}$-eGFP, sst2A-eGFP, and P2X2-YFP. Whereas cumulated fluorescence reached $800 \mu \mathrm{m}$ for $5-\mathrm{HT}_{1 \mathrm{~A}}$-eGFP (dendrites only), and 900-1100 $\mu \mathrm{m}$ for sst2A-eGFP and P2X2-YFP (dendrites and axons), 5- $\mathrm{HT}_{3 \mathrm{~A}}$-HA fluorescence did not exceed $100-200 \mu \mathrm{m}$ from cell bodies. When we compared transfections performed from 5 DIV (Fig. 3A) to 12 DIV (Fig. 3B) (48 h expression), we observed an increasing proportion of neurons showing a distal targeting of $5-\mathrm{HT}_{3 \mathrm{~A}}-\mathrm{HA}$ receptors. $5-\mathrm{HT}_{3 \mathrm{~A}} \mathrm{R}-\mathrm{HA}$ showed a delayed distal localization (fluorescence detected at distances $>100-200 \mu \mathrm{m}$ from cell bodies) only in a subpopulation of transfected neurons representing $11.4 \pm 1.2 \%$ at $5 \mathrm{DIV}$, and slowly increasing to $30 \%-40 \%$ after 7 DIV (Fig. 3E, blue area). The population of neurons that were not targeting $5-\mathrm{HT}_{3 \mathrm{~A}} \mathrm{R}-\mathrm{HA}$ distally could not be attributable to a degenerating process due to transfection, as shown by the integrity of their dendritic tubulin network (Fig. 3A). When transfected at $12 \mathrm{DIV}$, the discrepancy between neurons expressing $5-\mathrm{HT}_{3 \mathrm{~A}} \mathrm{R}-\mathrm{HA}$ proximally and neurons expressing the receptor distally increased, and surface labeling of the HA epitope revealed that only this latter population expressed the receptor at the surface (Fig. $3 B$ ). These results are consistent with the existence of two populations of neurons in regards to $5-\mathrm{HT}_{3 \mathrm{~A}} \mathrm{R}$ expression: one devoid of a targeting ma- 

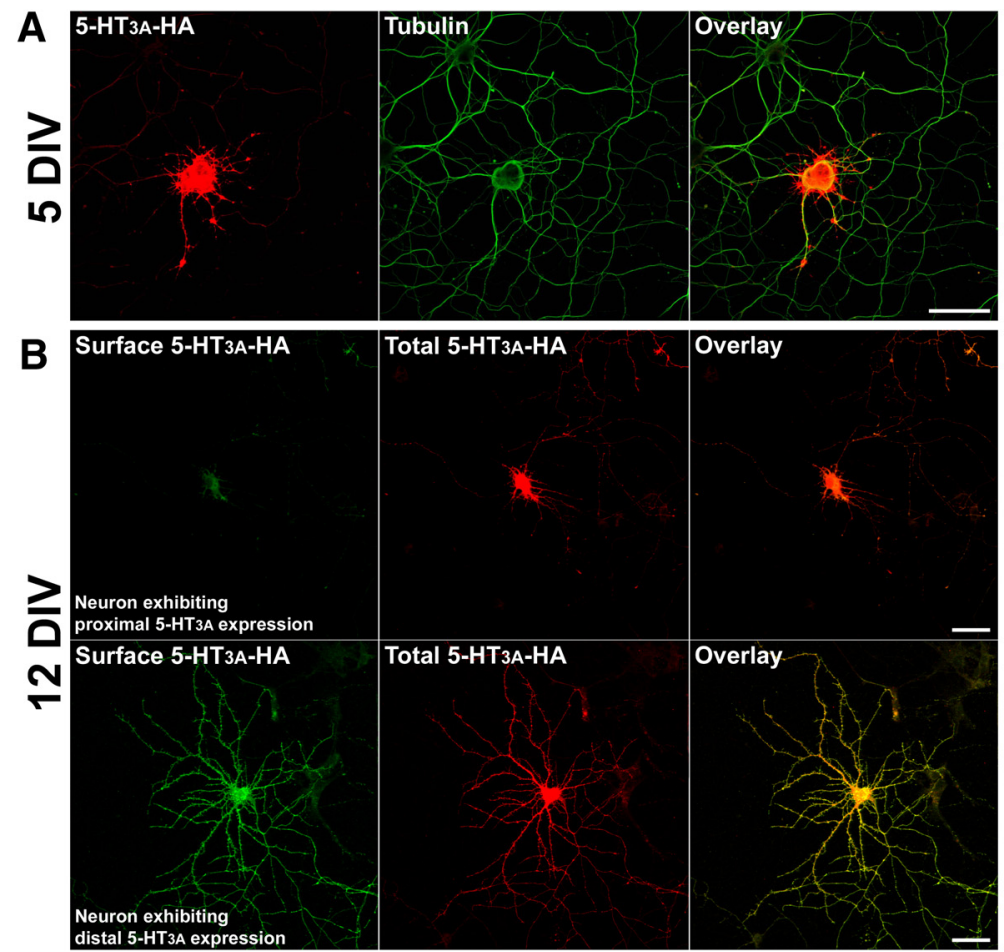

\section{C}
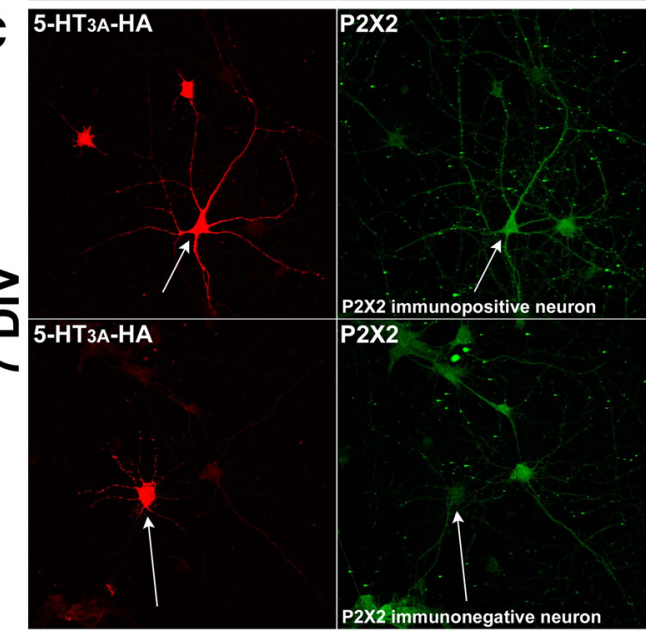

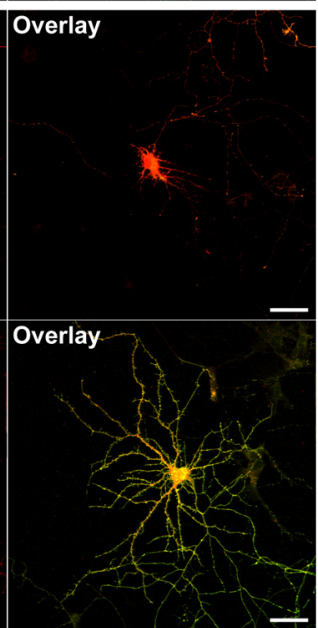

Overlay

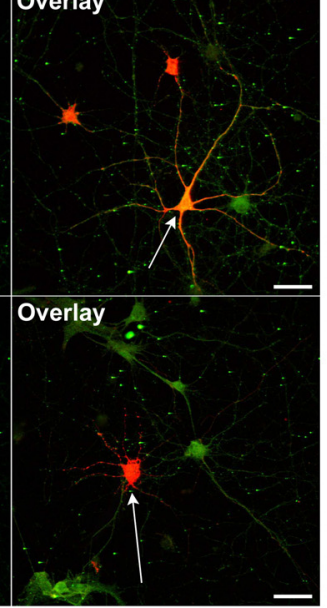

D
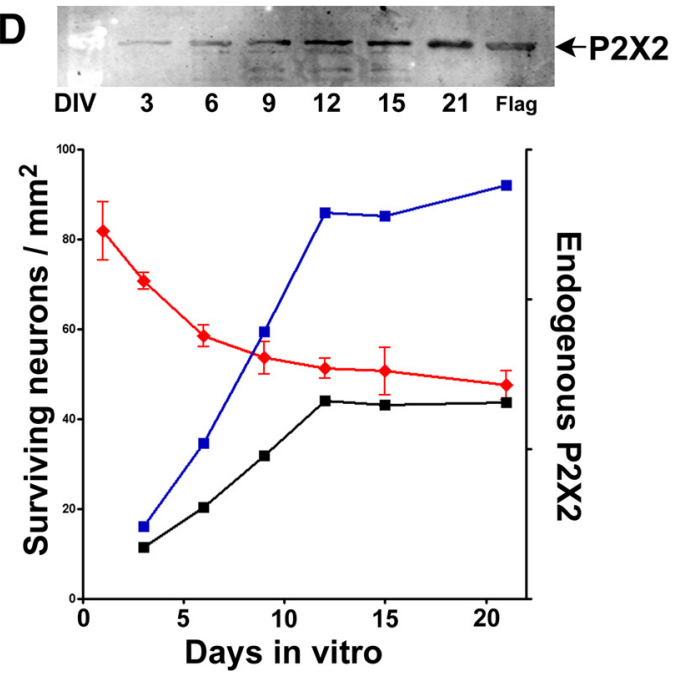

E

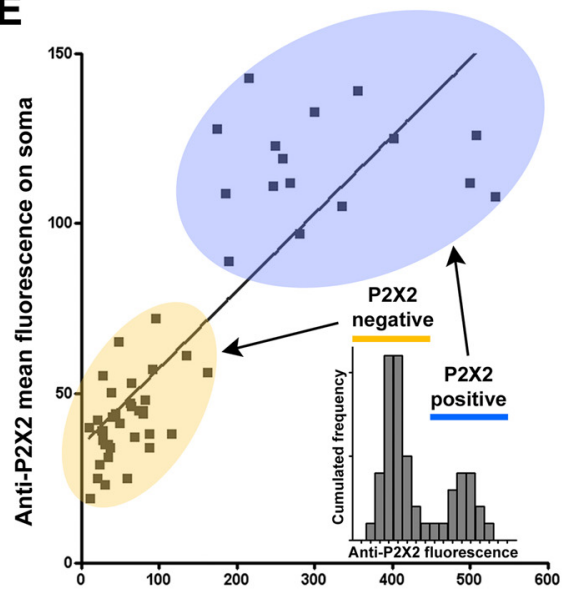

Anti-5-HT3A-HA fluorescence detection limit $(\mu \mathrm{m})$

Figure 3. $5-\mathrm{HT}_{3 \mathrm{~A}}$ receptor distal targeting is dependent on endogenous P2X2 receptors. Hippocampal neurons were transfected at $(\boldsymbol{A}) 5 \mathrm{DIV},(\boldsymbol{B}) 12 \mathrm{DIV}$, or $(\boldsymbol{C}) 7 \mathrm{DIV}$, with 5 -HT ${ }_{3 \mathrm{~A}} \mathrm{R}-\mathrm{HA}$. Immunofluorescence detection was performed with the following: $\boldsymbol{A}$, anti-HA (red) and anti-tubulin (green) antibodies; $\boldsymbol{B}$, anti-HA antibodies without permeabilization (green), and then anti-HA antibodies after permeabilization (red); or C, anti-HA (red) and anti-P2X2 (green) antibodies. Scale bars, $50 \mu \mathrm{m}$. D, Endogenous P2X2R (arbitrary units) were quantified by Western blot (black line) in hippocampal cultures at the indicated times (DIV). Surviving neurons were counted for each condition (red line), and the amount of endogenous P2X2R was divided by the number of live neurons in the culture at each time (blue line, endogenous P2X2/surviving neurons). $E$, The intensity of mean endogenous anti-P2X2R immunofluorescence (arbitrary units) measured on neuron somas was plotted versus the distance of the $5-\mathrm{HT}_{3 \mathrm{~A}}$ - $\mathrm{HA}$ detection limit (above background) along the longest immunolabeled neurite at $7 \mathrm{DIV}$ (C). The cumulated frequency distribution of P2X2R mean fluorescence intensity on somas (inset) revealed the existence of two populations of neurons ( $n=51$, bimodal distribution, median $=50)$ : $P 2 \times 2$ immunonegative $\left(68.3 \%, \mu^{1}=47\right.$, quartiles $=$ 40) and P2X2 immunopositive $\left(31.6 \%, \mu^{2}=121\right.$, quartiles $\left.=110\right)$. Only P2X2R-immunopositive neurons (example in $C$ ) expressed 5 - $\mathrm{HT}_{3 \mathrm{~A}} \mathrm{R}$ distally (linear regression, $r^{2}=0.71, p<0.0001$ ).

chinery for these receptors and another one expressing a distally targeting machinery with a slow onset.

\section{$5-\mathrm{HT}_{3 \mathrm{~A}}$ receptor targeting in distal dendrites and axons is neuron phenotype dependent}

Primary cultures of hippocampal neurons contain two major neuronal populations: large pyramidal neurons that are mainly glutamatergic (Graves et al., 2012), and interneurons, some of them GABAergic (Benson et al., 1994). However, we could not find any correlation between the capability of neurons to distally address $5-\mathrm{HT}_{3 \mathrm{~A}} \mathrm{R}$ and the size of the cell bodies, the shape of the neurons, or GAD65 immunolabeling (data not shown). Instead, we found a positive correlation between the distal localization of $5-\mathrm{HT}_{3 \mathrm{~A}}-\mathrm{HA}$ and the presence of endogenous $\mathrm{P} 2 \mathrm{X} 2 \mathrm{R}$ in these neurons. We labeled 5- $\mathrm{HT}_{3 \mathrm{~A}} \mathrm{R}-\mathrm{HA}$-transfected hippocampal neurons at an intermediate differentiation time (7 DIV) with anti-P2X2 antibodies (Fig. 3C). The cumulated frequency diagram of anti-P2X2 intensity (Fig. $3 E$, inset) revealed that hippocampal neurons were distributed in two populations (bimodal anti-P2X2 fluorescence distribution plotted against cumulated frequency). By plotting the average P2X2R fluorescence measured on cell bodies versus the detection limit of $5-\mathrm{HT}_{3 \mathrm{~A}} \mathrm{R}-\mathrm{HA}$ immunolabeling (above background) along the longest immunopositive neurite (Fig. 3E), a correlation was observed (linear 
A

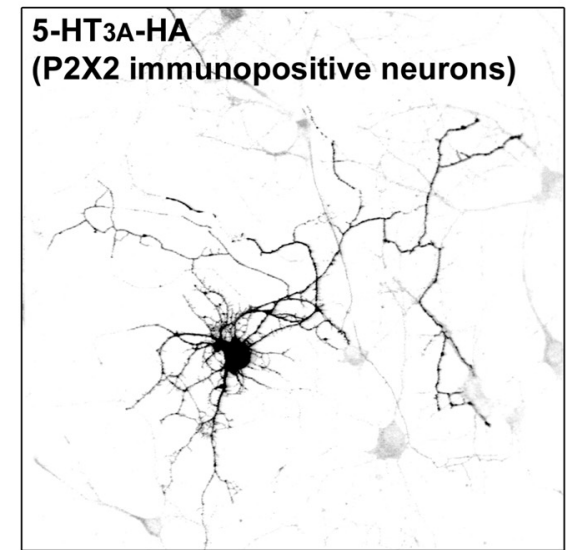

SiRNA(P2X2)

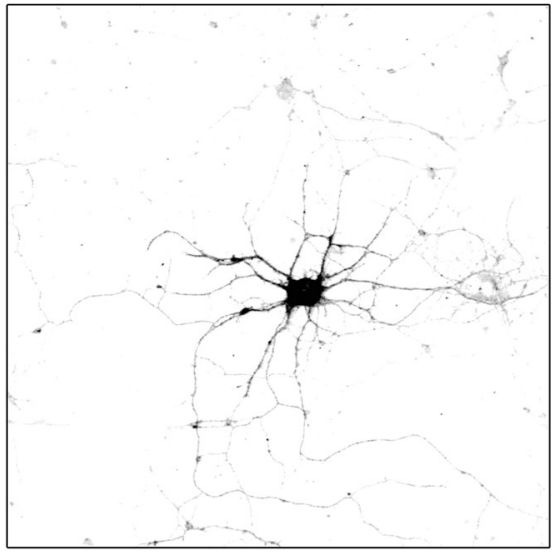

C

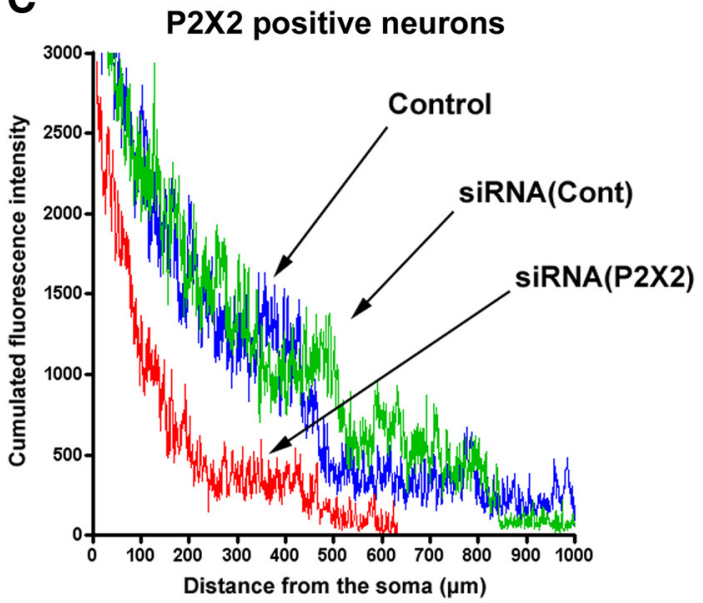

SiRNA(Cont)

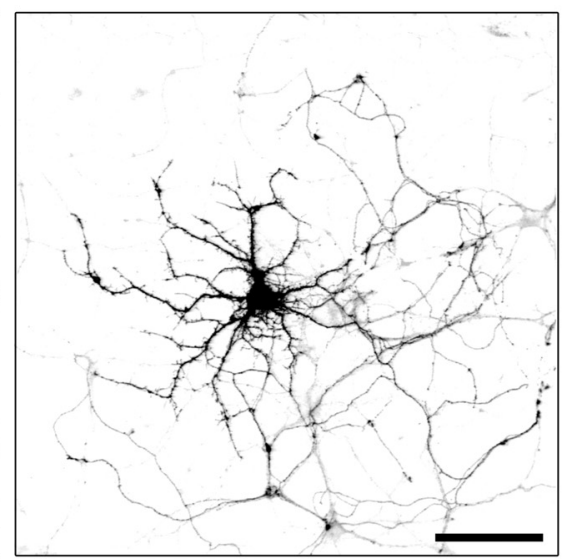

D
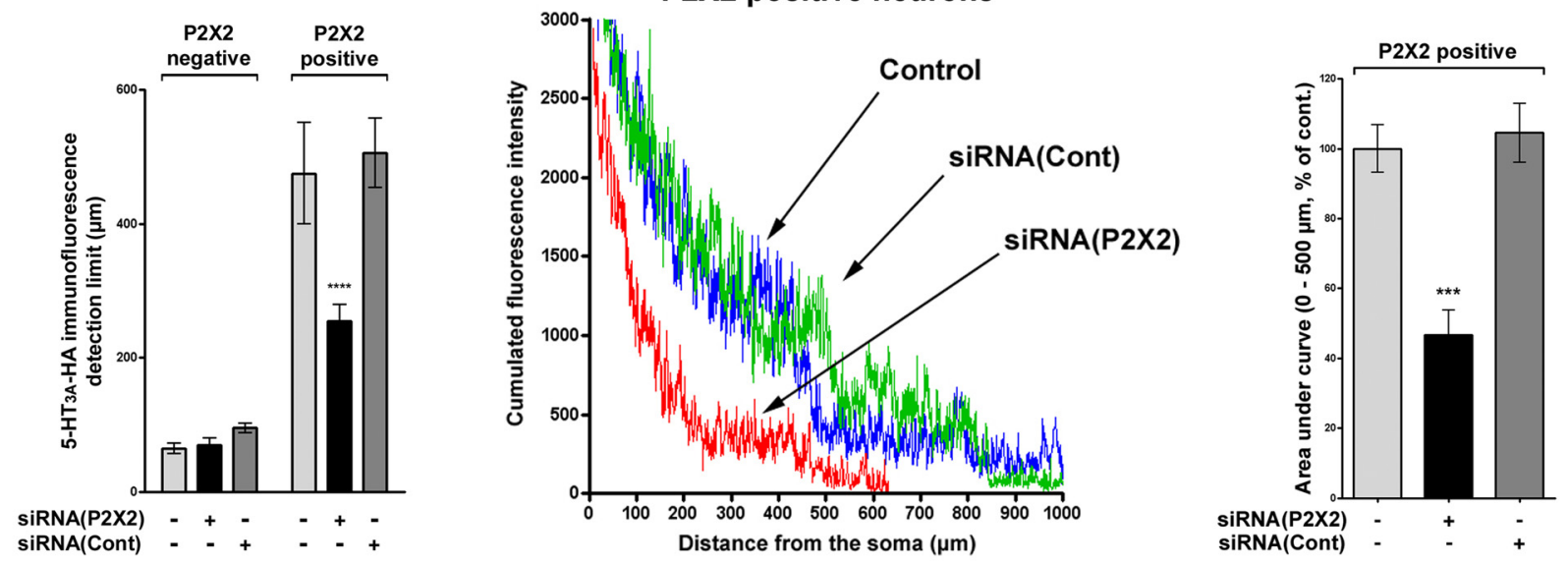

Figure 4. P2X2 receptor depletion inhibits $5-\mathrm{HT}_{3 \mathrm{~A}}$ receptor targeting toward distal neurites. Hippocampal neurons were transfected at $7 \mathrm{DIV}$ with the $5-\mathrm{HT}_{3 \mathrm{~A}} \mathrm{R}-\mathrm{HA}$ alone or cotransfected with the 5-HT $\mathrm{HA}_{3 \mathrm{~A}} \mathrm{R}-\mathrm{HA}$ plus siRNA against endogenous $\mathrm{P} 2 \mathrm{X} 2 \mathrm{R}$ or control siRNA for $48 \mathrm{~h}$. $\mathrm{A}$, Immunofluorescence detection of $5-\mathrm{HT}_{3 \mathrm{~A}} \mathrm{R}-\mathrm{HA}$ in representative neurons belonging to the $\mathrm{P} 2 \mathrm{X} 2$-immunopositive subpopulation. Scale bar, $50 \mu \mathrm{m} . B, 5-\mathrm{HT}_{3 \mathrm{~A}} \mathrm{R}$-HA immunofluorescence detection limits along the longest neurite (one neurite per neuron) were measured for each transfected neuron, and the neurons belonging to the P2X2-immunonegative and P2X2-immunopositive groups were represented separately. After RNA interference of endogenous $P 2 X 2 R$, the 5- $\mathrm{HT}$ 3A $\mathrm{R}-\mathrm{HA}$ immunofluorescence detection limit was significantly lower in neurites of P2X2-immunopositive neurons only. Bars indicate mean \pm SEM; $n=40-50$. ${ }^{* * * *} p<0.0001$ (two-way ANOVA with Bonferroni's post hoc test). C, Cumulated fluorescence intensity profiles of $5-\mathrm{HT}_{3 \mathrm{~A}} \mathrm{R}$ - $\mathrm{HA}$ (arbitrary units) along the longest neurite of P2X2-immunopositive monitored neurons ( $\mu \mathrm{m}$ ) in control conditions (blue) compared with siRNA(P2X2) (red) and siRNA(Cont) (green). $\boldsymbol{D}$, Areas under individual curves (cumulated in $\boldsymbol{C}$ ), for distances of $0-500 \mu \mathrm{m}$, were averaged. The 5- $\mathrm{HT}_{3 \mathrm{~A}} \mathrm{R}-\mathrm{HA}$ immunofluorescence intensity is significantly lower in neurites after RNA interference of endogenous P2X2R. Bars represent the mean \pm SEM $(n=20-30) .{ }^{* * *} p<0.001$ (one-way ANOVA with Dunnett's Multiple Comparison post hoc test).

regression, $\left.n=51, r^{2}=0.71, p<0.0001\right)$, showing that the distal targeting of $5-\mathrm{HT}_{3 \mathrm{~A}} \mathrm{R}$ was linked with the expression of native $\mathrm{P} 2 \mathrm{X} 2 \mathrm{R}$ in the neurons. Moreover, the bimodal distribution corresponded to two neuronal populations: a low intensity (background, P2X2R negative) and a threefold higher intensity (P2X2R positive), representing $68.6 \%$ and $31.4 \%$, respectively, of the total. These two populations could be defined by setting a fluorescence cutoff at the minimum value of the fitted curve (Fig. 3E, inset). Measurements of the lengths of detectable $5-\mathrm{HT}_{3 \mathrm{~A}} \mathrm{R}-\mathrm{HA}$ fluorescence yielded corresponding values of $58 \pm$ $9 \mu \mathrm{m}$ and $312 \pm 29 \mu \mathrm{m}$ (mean \pm SEM, $n=51, t$ test, significant difference, $p<0.0001$ ), respectively, for the two populations (Fig. 3E, colored areas). The same results were obtained with human HA-tagged h5- $\mathrm{HT}_{3 \mathrm{~A}}$ subunits in which the HA tag was introduced in the $\mathrm{N}$-terminal domain between amino acids 5 and 6 (Boyd et al., 2003) (data not shown), suggesting that this correlation was not rodent specific or induced by the tag position. Quantification of SDS-PAGE analysis followed by immunoblotting (Fig. 3D) confirmed the increasing presence of endogenous
P2X2R in cultured hippocampal neurons from 3 to $10-11$ DIV, followed by a plateau from 12 to $21 \mathrm{DIV}$, an observation consistent with previous reports of $\mathrm{P} 2 \mathrm{X} 2 \mathrm{R}$ expression in the hippocampus (North, 2002; Khakh et al., 2003). As a result, the slow onset of native P2X2R expression in the culture explains the delayed capacity of the P2X2-immunopositive subset of neurons to distally address $5-\mathrm{HT}_{3 \mathrm{~A}} \mathrm{R}$.

\section{$5-\mathrm{HT}_{3 \mathrm{~A}}$ receptor targeting to distal dendrites and axons is} dependent on endogenous $\mathrm{P} 2 \mathrm{X} 2$ receptors

The dependency of transfected $5-\mathrm{HT}_{3 \mathrm{~A}} \mathrm{R}$ on native P2X2R expression for their distal neuritic localization was confirmed by RNA interference. We found that simultaneous transfection of 5- $\mathrm{HT}_{3 \mathrm{~A}} \mathrm{R}-\mathrm{HA}$ and siRNA(P2X2) at 7 DIV (i.e., inhibition of de novo expressed $\mathrm{P} 2 \mathrm{X} 2 \mathrm{R}$ ) was optimal to significantly affect $5-\mathrm{HT}_{3 \mathrm{~A}} \mathrm{R}$ localization. Hippocampal neurons were transfected with $5-\mathrm{HT}_{3 \mathrm{~A}} \mathrm{R}-\mathrm{HA}$, with or without siRNA(P2X2) or control siRNA at $7 \mathrm{DIV}$, and the neurons were simultaneously quantified for the following: (1) their anti-P2X2 fluorescence intensity on 


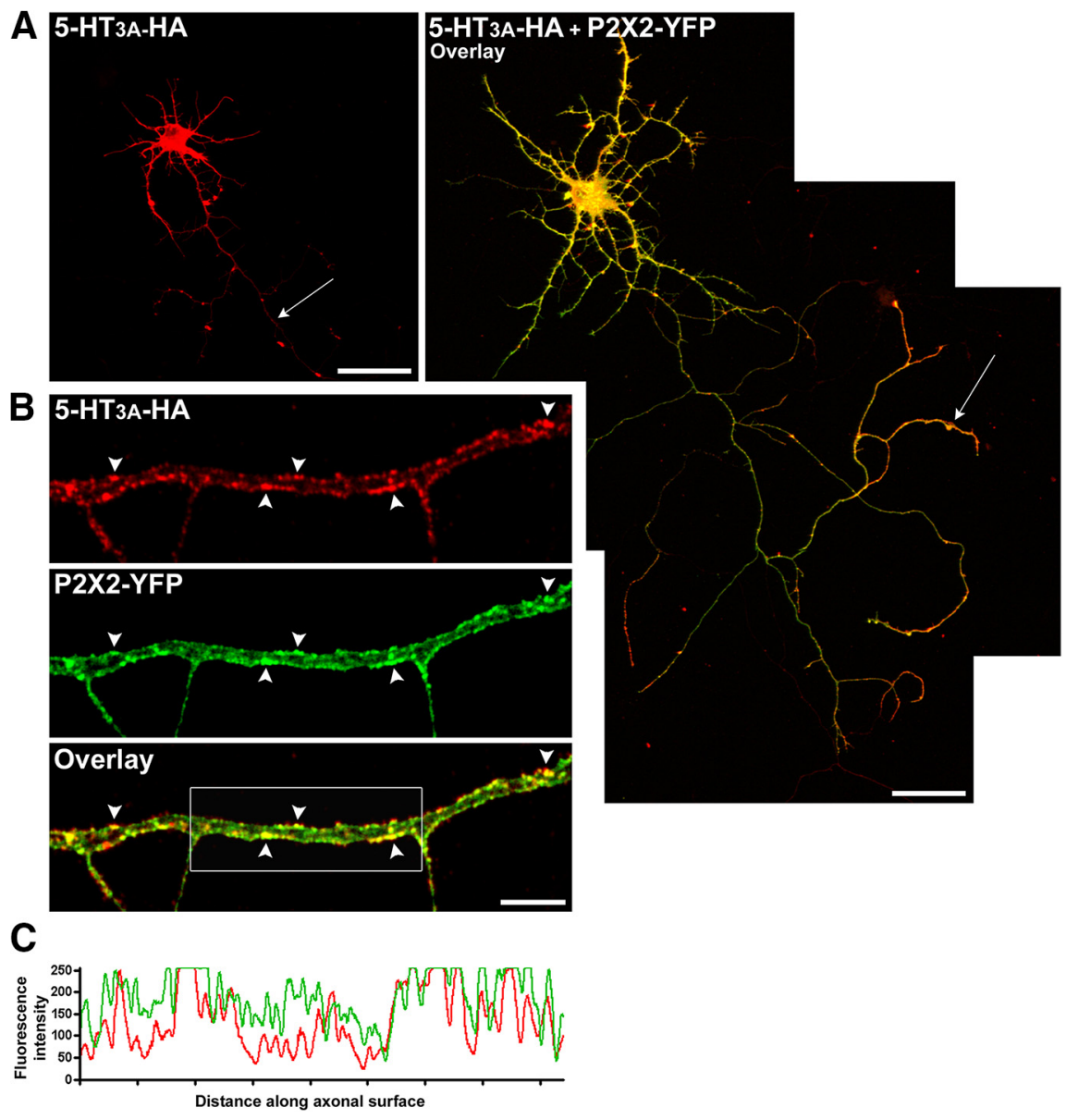

Figure 5. $5-\mathrm{HT}_{3 \mathrm{~A}}$ and $\mathrm{P} 2 \mathrm{X} 2$ receptors colocalize in common surface clusters. $A, 5-\mathrm{HT}_{3 \mathrm{~A}} \mathrm{R}-\mathrm{HA}$ was transfected alone or cotransfected with P2X2R-YFP in hippocampal neurons at 7 DIV. Immunofluorescence detection of both receptors (red represents $5-\mathrm{HT}_{3 \mathrm{~A}} \mathrm{R}-\mathrm{HA}$; green represents P2X2-YFP) was performed after $48 \mathrm{~h}$. The presence of transfected P2X2R in the same neurons enhanced the distal trafficking of $5-\mathrm{HT}_{3 \mathrm{~A}} \mathrm{R}$ in all neurites, particularly in axons (arrows). Scale bar, $50 \mu \mathrm{m}$. B, Magnification of an axonal section reveals that $5-\mathrm{HT}_{3 \mathrm{~A}}$ R and $\mathrm{P} 2 \mathrm{X} 2 \mathrm{R}$ colocalize in common surface clusters (arrowheads). $C$, Fluorescence profiles of both labels along a polyline drawn through the surface clusters (boxed section). Scale bar, $5 \mu \mathrm{m}$.

the soma, (2) their anti-HA $\left(5-\mathrm{HT}_{3 \mathrm{~A}} \mathrm{R}\right)$ fluorescence intensity along their longest neurite, and (3) the anti-HA $\left(5-\mathrm{HT}_{3 \mathrm{~A}} \mathrm{R}\right)$ fluorescence detection limit for their longest labeled neurite (Fig. 4). Figure $4 A$ shows characteristic neurons for the three conditions, in the population of P2X2R-immunopositive neurons. Quantification of $5-\mathrm{HT}_{3 \mathrm{~A}} \mathrm{R}-\mathrm{HA}$ detection limit (above background) revealed that siRNA(P2X2) reduced significantly the average distance of anti-HA detection by $47 \%(53.4 \pm 5.2 \%$ of control, two-way ANOVA, $n=46, p<0.0001$ ) in P2X2R-immunopositive neurons (Fig. $4 B$ ), whereas control siRNA had no effect $(106.6 \pm 10.9 \%$ of control, two-way ANOVA, $n=49, p<$ 0.0001). There was no significant effect of siRNAs on P2X2Rimmunonegative neurons (Fig. 4B). When cumulated fluorescence intensity profiles along the longest neurite (one neurite per neuron) for the P2X2R-immunopositive subset of $5-\mathrm{HT}_{3 \mathrm{~A}} \mathrm{R}-\mathrm{HA}$ transfected neurons were plotted, the depletion of $5-\mathrm{HT}_{3 \mathrm{~A}}-\mathrm{HA}$ receptor expression in the neurites was clear cut for siRNA(P2X2)-treated neurons but was indistinguishable from the control for siRNA(Control) (Fig. 4C). Quantification of the areas under the curves for each P2X2R-positive neuron $(0-500 \mu \mathrm{m}$ from soma) yielded an average inhibition of $53 \%$ (46.6 $\pm 7.2 \%$ of control, two-way ANOVA, $n=46, p<$ $0.0001)$ for siRNA(P2X2) and no effect of control siRNA (104.5 $\pm 8.5 \%$ of control, two-way ANOVA, $n=49, p<0.0001$ ).
Because this protocol of siRNA interference only inhibited de novo expression of endogenous P2X2R (i.e., simultaneously expressed with transfected $5-\mathrm{HT}_{3 \mathrm{~A}}-\mathrm{HA}$ ) and did not affect the receptors already present at 7 DIV, no clear decrease of P2X2 signal could be detected in immunofluorescence at the level of cell somas or on immunoblots (data not shown). Nevertheless, these results demonstrate the dependency of $5-\mathrm{HT}_{3 \mathrm{~A}} \mathrm{R}$ on P2X2R for their localization in distal neurites and suggest that both receptors probably undergo a common trafficking fate at an early stage.

\section{5- $\mathrm{HT}_{3 \mathrm{~A}}$ and $\mathrm{P} 2 \mathrm{X} 2$ colocalize in common surface clusters}

We then cotransfected hippocampal neurons with both tagged $5-\mathrm{HT}_{3 \mathrm{~A}}$ and tagged P2X2 subunits to visualize how the presence of additional P2X2R would influence the neuronal distribution and topology of $5-\mathrm{HT}_{3 \mathrm{~A}} \mathrm{R}$. Figure $5 A$ shows a typical neuron transfected with $5-\mathrm{HT}_{3 \mathrm{~A}} \mathrm{R}-\mathrm{HA}$ alone and one cotransfected with $5-\mathrm{HT}_{3 \mathrm{~A}}-\mathrm{HA}$ plus P2X2-YFP subunits. The main effect of the presence of both transfected receptors in the same neurons was a redistribution of $5-\mathrm{HT}_{3 \mathrm{~A}} \mathrm{R}$ subcellular localization in the neuritic processes. $5-\mathrm{HT}_{3 \mathrm{~A}} \mathrm{R}$ were "boosted" to fulfill the entire dendritic tree and also the axonal arborization up to the very end. Magnification of an axonal section revealed that $5-\mathrm{HT}_{3 \mathrm{~A}} \mathrm{R}-\mathrm{HA}$ and $\mathrm{P} 2 \mathrm{X} 2 \mathrm{R}-\mathrm{YFP}$ were both expressed under a diffuse and a clustered component. Colocalization of the two receptors within these surface clusters was largely observed in the majority of cotransfected neurons as shown by the correspondence between fluorescence profiles (Fig. $5 B, C$ ), indicating physical proximity between the two proteins during the trafficking process.

The $\mathrm{P} 2 \mathrm{X} 2$ receptor is a specific routing partner of the $5-\mathrm{HT}_{3 \mathrm{~A}}$ receptor for axonal targeting

The rigorous quantification of $5-\mathrm{HT}_{3 \mathrm{~A}} \mathrm{R}$ subcellular redistribution by $\mathrm{P} 2 \mathrm{X} 2 \mathrm{R}$ cotransfection within hippocampal neurons required to first solve two technically interfering drawbacks: (1) the reduction of the endogenous $\mathrm{P} 2 \mathrm{X} 2 \mathrm{R}$ component contribution to $5-\mathrm{HT}_{3 \mathrm{~A}} \mathrm{R}$ redistribution; and (2) the isolation of the axonal and dendritic components of fluorescence profile measurements. Both problems were solved by transfecting early plated neurons (4-5 DIV) because, at that time, (1) native P2X2R are still expressed at low levels (Fig. 3D) and contribute to distal targeting of $5-\mathrm{HT}_{3 \mathrm{~A}} \mathrm{R}$ for $<10 \%$ of neurons (Fig. $6 \mathrm{D}$ ); and (2) the dendritic trees of neurons are still poorly developed, whereas axons are in rapid growing phase and are unambiguously characterized from dendrites on the basis of their shapes and sizes (Fig. 6A) without the use of axonal or dendritic specific markers that are not selective of their respective compartments in neurons that are not completely differentiated (4-10 DIV). Thus, $5-\mathrm{HT}_{3 \mathrm{~A}} \mathrm{R}-\mathrm{HA}$ and P2X2R-YFP cotransfection was performed on 4-5 DIV neurons, 


\section{5-HT3A-HA + P2X2-YFP}

A

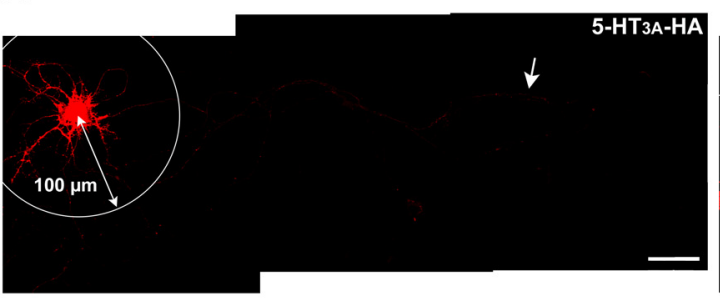

5-HT3A-HA + eGFP
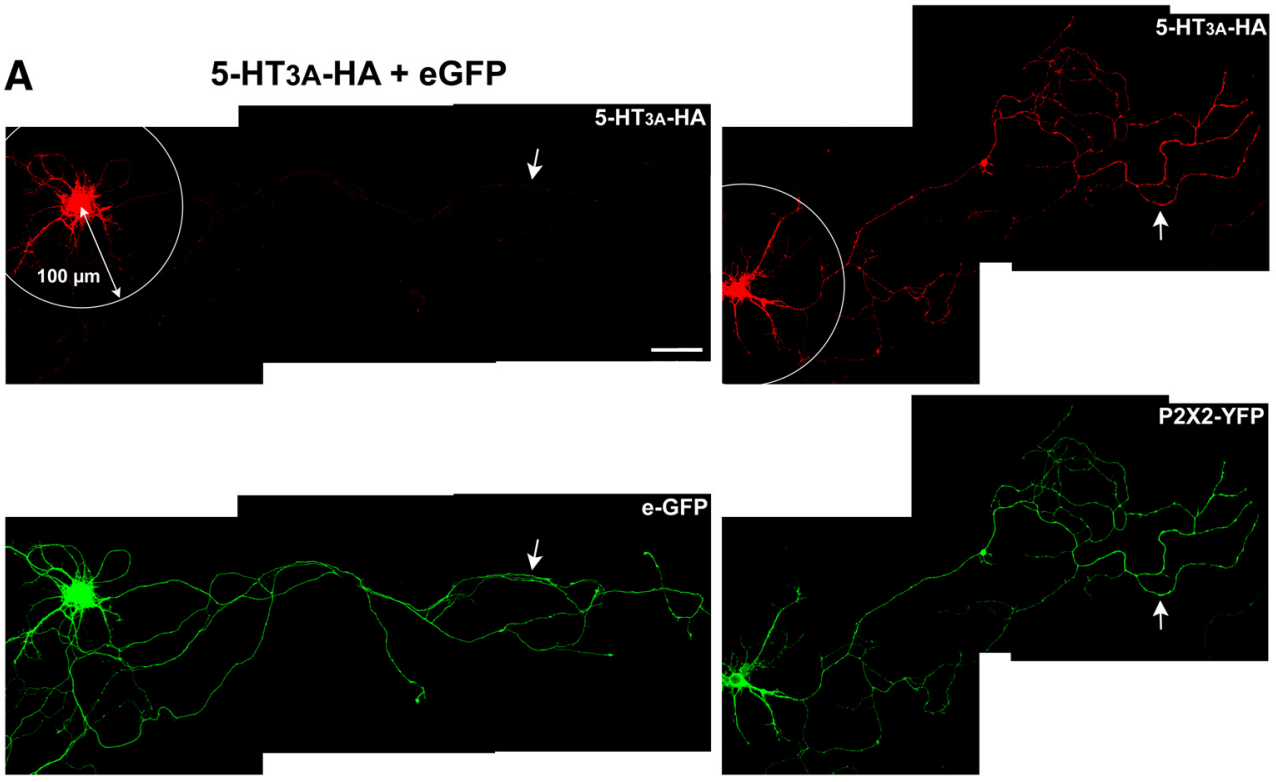

B

5-HT3A-HA axonal profiles

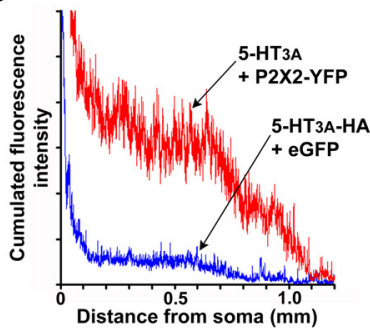

C eGFP and P2X2-YFP axonal profiles
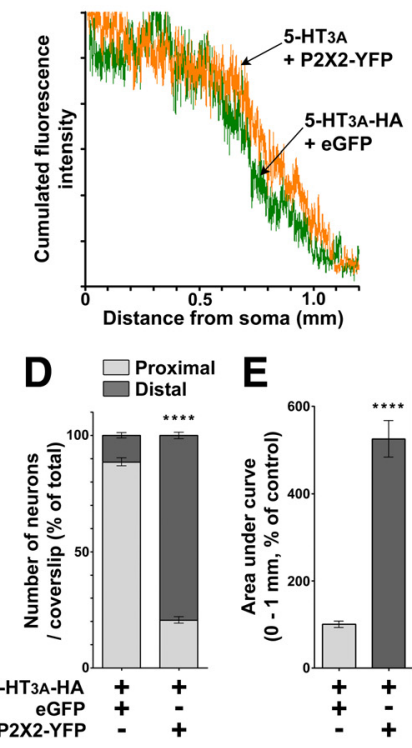

Figure 6. $\mathrm{P} 2 \mathrm{X} 2$ receptors induce $5-\mathrm{HT}_{3 \mathrm{~A}}$ receptor targeting in axons. Hippocampal neurons were cotransfected at $4-5$ DIV with 5- $\mathrm{H}_{3 \mathrm{~A}} \mathrm{R}-\mathrm{HA}$ plus eGFP or 5-HT $\mathrm{R}_{3 \mathrm{~A}} \mathrm{HA}$ plus $\mathrm{P} 2 \mathrm{X} 2-\mathrm{YFP}$. $\mathrm{A}$, Immunofluorescence detection (red represents anti-HA; green represents anti-eGFP) was performed $48 \mathrm{~h}$ after transfection. Arrows indicate the axons. Scale bar, $50 \mu \mathrm{m}$. $\boldsymbol{B}$, Cumulated fluorescence intensity profiles of $5-\mathrm{HT}_{3 A} \mathrm{R}-\mathrm{HA}$ along the axons (longest path, $n=30$ ) for $5-\mathrm{HT}_{3 \mathrm{~A}} \mathrm{R}$-HA plus eGFP (blue) or $5-\mathrm{HT} \mathrm{T}_{3 \mathrm{R}} \mathrm{R}-\mathrm{HA}$ plus P2X2-YFP (red). C, Cumulated fluorescence intensity profiles of eGFP and P2X2-YFP along the same axons ( $n=30$ ) for $5-\mathrm{HT}_{3 \mathrm{~A}} \mathrm{R}-\mathrm{HA}$ plus eGFP (green) or $5-\mathrm{HT}_{3 \mathrm{~A}} \mathrm{R}-\mathrm{HA}$ plus P2X2-YFP (orange). $D$, Quantification of the number of neurons exhibiting 5-HT ${ }_{3 \mathrm{~A}} \mathrm{R}-\mathrm{HA}$ immunofluorescence at distances above (distal) or below (proximal) $100 \mu \mathrm{m}$ from somas for $5-\mathrm{HT}_{3 \mathrm{~A}} \mathrm{R}-\mathrm{HA}$ plus eGFP or 5 - $\mathrm{HT} \mathrm{T}_{3 \mathrm{~A}} \mathrm{R}$-HA plus P2X2-YFP. Bars represent the relative proportions of the two groups (mean \pm SEM) for each cotransfection condition (tw0-way ANOVA, $n=324$ and $n=399$, respectively, $p<0.0001$ ). $E$, Areas under individual curves (cumulated in $\boldsymbol{B}$ ) for distances of $0-1000 \mu m$ were averaged. Bars represent the mean $\pm \mathrm{SEM} ; n=30$. ${ }^{* * *} p<0.0001$ (two-way ANOVA with Bonferroni's Multiple Comparison post hoc test).

and quantitative fluorescence analysis was performed on the total number of transfected neurons for each condition (Fig. 6). Typical neurons expressing either $5-\mathrm{HT}_{3 \mathrm{~A}} \mathrm{R}-\mathrm{HA}$ and eGFP or $5-\mathrm{HT}_{3 \mathrm{~A}} \mathrm{R}-\mathrm{HA}$ and P2X2R-YFP are shown on Figure 6 A. Cotransfection of P2X2R-YFP changed completely the targeting of $5-\mathrm{HT}_{3 \mathrm{~A}} \mathrm{R}-\mathrm{HA}$ from (proximal) dendritic only to (distal) dendritic and axonal, whereas eGFP did not induce $5-\mathrm{HT}_{3 \mathrm{~A}} \mathrm{R}-\mathrm{HA}$ expression in the axon, thereby demonstrating that the $5-\mathrm{HT}_{3 \mathrm{~A}} \mathrm{R}$ retargeting was not the consequence of a nonspecific artifact linked to protein overexpression. The totality of $5-\mathrm{HT}_{3 \mathrm{~A}} \mathrm{R}-\mathrm{HA}-$ immunopositive neurons was then classified into two categories on the basis of their expression of $5-\mathrm{HT}_{3 \mathrm{~A}} \mathrm{R}-\mathrm{HA}$ fluorescence at distances under (proximal) or above (distal) $100 \mu \mathrm{m}$ from somas (Fig. 6A), and neuron counts for each condition were represented in percentage of total neurons counted (Fig. $6 D$ ). When neurons were cotransfected with $5-\mathrm{HT}_{3 \mathrm{~A}} \mathrm{R}-\mathrm{HA}$ and eGFP, the proximal and distal groups represented $88.6 \pm 1.8 \%$ and $11.4 \pm 1.2 \%$, respectively, of the total neurons counted (mean \pm SEM, $n=$ 324) and did not differ significantly from neurons transfected with 5- $\mathrm{HT}_{3 \mathrm{~A}} \mathrm{R}-\mathrm{HA}$ alone (data not shown). When neurons were cotransfected with 5- $\mathrm{HT}_{3 \mathrm{~A}} \mathrm{R}-\mathrm{HA}$ and $\mathrm{P} 2 \mathrm{X} 2 \mathrm{R}-\mathrm{YFP}$, the proximal and distal groups were changed to $20.6 \pm 1.4 \%$ and $79.4 \pm 1.4 \%$, respectively ( $n=399$ ). Comparing the relative number of neurons with proximal and distal labeling in the two cotransfection experiments revealed a significant difference (two-way ANOVA, $p<0.0001)$. Fluorescence profiles along the entire axonal arborization (longest path) were measured on a representative subset of neurons $(n=30)$, and cumulated fluorescence profiles for 5-HT ${ }_{3 \mathrm{~A}}$ R-HA (Fig. 6B) and eGFP or P2X2R-YFP (Fig. 6C) fluorescence were plotted. Quantification of the areas under individual fluorescence curves (normalized for $5-\mathrm{HT}_{3 \mathrm{~A}} \mathrm{R}-\mathrm{HA}+\mathrm{eGFP}$ mean value; Fig. $6 E$ ) showed that the amount of $5-\mathrm{HT}_{3 \mathrm{~A}} \mathrm{R}$ in the axons was dramatically increased by the presence of P2X2R in the same neurons $(+525.3 \pm 42.1 \%)$ with statistical significance (one-way ANOVA, $n=30, p<0.0001$ ). The relatively lower, but not null, quantity of $5-\mathrm{HT}_{3 \mathrm{~A}} \mathrm{R}$ present in axons of neurons cotransfected with e-GFP (Fig. $6 B$, blue curve) could be attributed to the contribution of the $11.4 \%$ of neurons already expressing native P2X2R (see above). Finally, axonal lengths were not different between the two groups as shown by eGFP and P2X2RYFP fluorescence profiles (Fig. 6C).

The specificity of the physical partnership between $5-\mathrm{HT}_{3 \mathrm{~A}}$ and $\mathrm{P} 2 \mathrm{X} 2$ receptors was evaluated by quantification of the colocalization of the clustered components of receptor fluorescence 


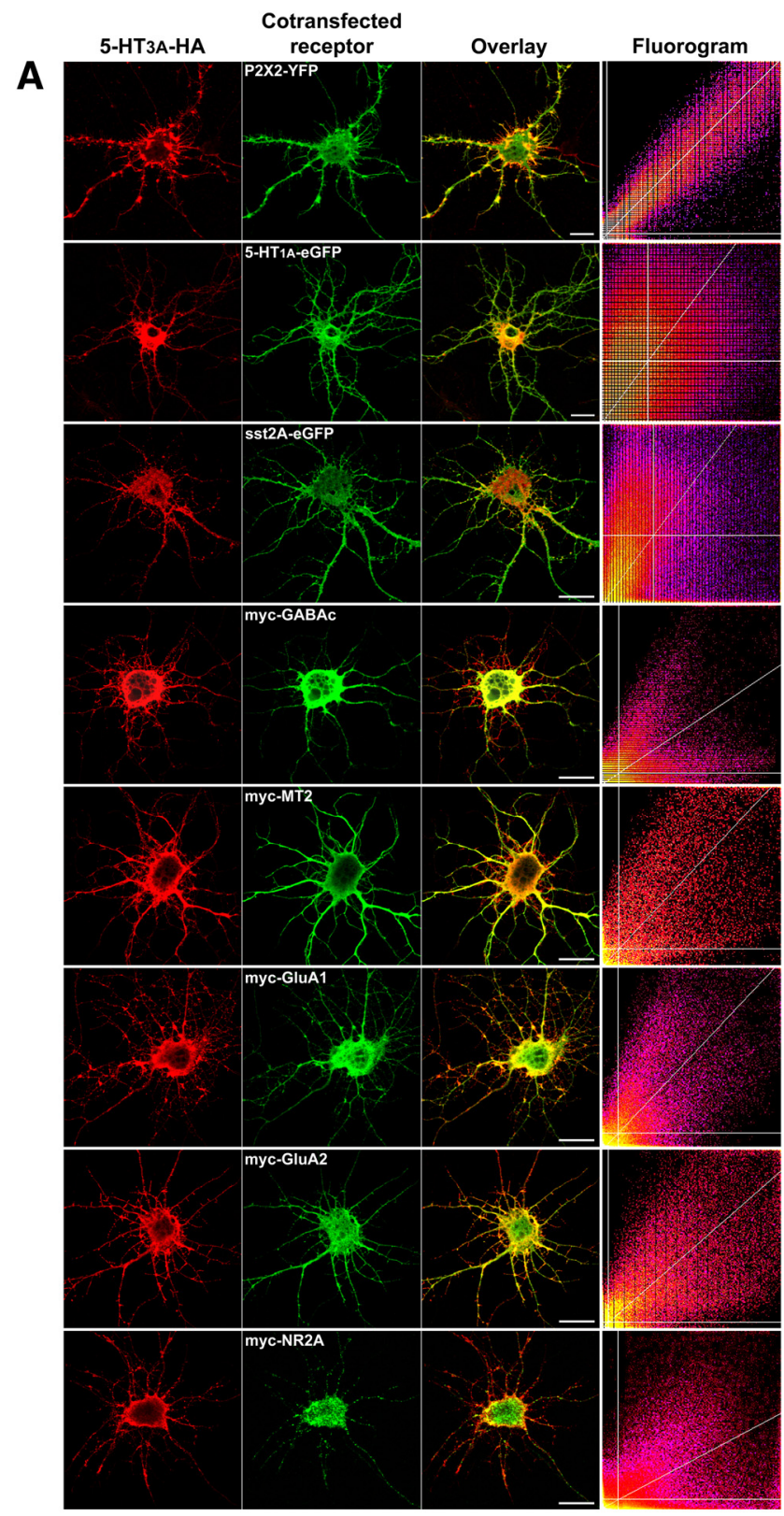

B

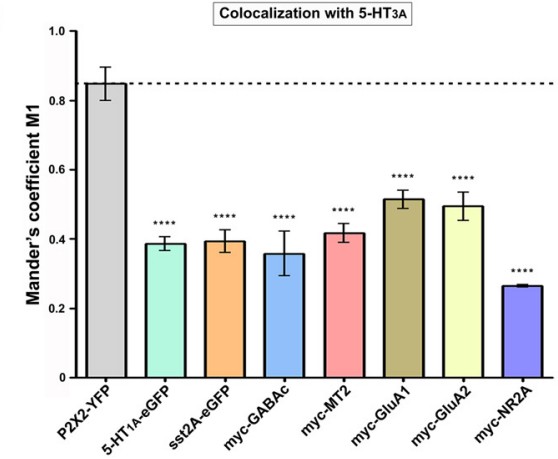

Figure 7. Specificity of the $5-\mathrm{HT}_{3 \mathrm{~A}}$ and $\mathrm{P} 2 \mathrm{X} 2$ receptor interaction. Hippocampal neurons were cotransfected at 7 DIV with 5- $\mathrm{HT}_{3 \mathrm{~A}}-\mathrm{HA}$ and P2X2-YFP, 5-HT $1 \mathrm{~A}^{-}$eGFP, sst2A-eGFP, myc$\operatorname{GABAC}(\rho 1)$, myc-MT2, myc-GluA1, myc-GluA2, or myc-NR2A subunits. $\boldsymbol{A}$, Immunofluorescence detection was performed after $48 \mathrm{~h}$ (red represents anti-HA; green represents anti-eGFP or anti-myc). Scale bars, $20 \mu \mathrm{m}$. ROI were chosen within the dendritic trees to select cluster-rich areas and avoid the center of large neurites, and colocalization was monitored with the JACOP plugin of ImageJ (manual thresholding). Corresponding fluorograms for each cotransfected in the dendritic tree, and comparison with other noninteracting receptors (Fig. 7). We chose this method rather than the quantification of the axonal distribution because it was appropriate for all receptors tested, all of them having a dendritic representation, whereas most of them were not axonal. Neurons were cotransfected with 5- $\mathrm{HT}_{3 \mathrm{~A}} \mathrm{R}-\mathrm{HA}$ and either P2X2R-YFP or seven other tagged receptors that were not described to functionally interact with $5-\mathrm{HT}_{3 \mathrm{~A}} \mathrm{R}$. ROI were chosen within the dendritic trees, and colocalization was monitored with the JACoP plugin of ImageJ (Bolte and Cordelières, 2006), using manual thresholding to restrict the quantification to the clustered component of $5-\mathrm{HT}_{3 \mathrm{~A}} \mathrm{R}-\mathrm{HA}$ immunostaining. Although colocalization of immunofluorescence signals cannot be considered as proof of physical interaction between proteins, we used this method to show that the absence of colocalization between noninteracting receptors could evidence the specificity of the $5-\mathrm{HT}_{3 \mathrm{~A}} / \mathrm{P} 2 \mathrm{X} 2 \mathrm{in}-$ teraction. Indeed, this method proved to distinguish between physically interacting receptors exhibiting coclustered dendritic distributions (Mander's M1 coefficient close to 0.8 , characteristic plume-shaped fluorograms) and noninteracting receptors characterized either by nonoverlapping clusters or by one receptor being clustered and the other exhibiting a diffuse component only (random overlap, Mander's M1 coefficient close to 0.4, diffuse or bimodal fluorograms) (Figs. $7 B, 8 C, 9 B$ ). Mander's $\mathrm{M} 1$ coefficients (percentage of clustered $5-\mathrm{HT}_{3 \mathrm{~A}} \mathrm{R}-\mathrm{HA}$ overlapping with the clustered component, when relevant, of the cotransfected receptor) are presented in Figure $7 B$. Moreover, none of the receptors yielding Mander's M1 coefficients $\sim 0.4$ changed significantly 5- $\mathrm{HT}_{3 \mathrm{~A}} \mathrm{R}-\mathrm{HA}$ distribution in either neuritic compartment (Fig. $7 \mathrm{~A}$ ), showing that $5-\mathrm{HT}_{3 \mathrm{~A}} \mathrm{R}$ retargeting by $\mathrm{P} 2 \mathrm{X} 2 \mathrm{R}$ was related to their specific physical receptor-receptor interaction.

\section{The 5- $\mathrm{HT}_{3 \mathrm{~A}}$ and $\mathrm{P} 2 \mathrm{X} 2$ physical interaction depends on 5-}

\section{$\mathrm{HT}_{3 \mathrm{~A}}$ IL2, but not on the P2X2 C-tail}

We have demonstrated previously that the functional crossinhibition between $5-\mathrm{HT}_{3 \mathrm{~A}}$ and $\mathrm{P} 2 \mathrm{X} 2$ receptors involved the C-terminal tail of the P2X2R and the IL2 domains of the cys-loop ionotropic receptors (Boué-Grabot et al., 2003), and that channel occlusion was subunit dependent in the case of $\mathrm{GABA}_{\mathrm{A}} \mathrm{R}$ (BouéGrabot et al., 2004a). To challenge whether the functional and physical couplings of 5- $\mathrm{HT}_{3 \mathrm{~A}}$ and $\mathrm{P} 2 \mathrm{X} 2$ receptors depended on the same peptidic domains, we prepared truncated forms of the P2X2R (Fig. $8 A$ ) and chimeras of the $5-\mathrm{HT}_{3 \mathrm{~A}} \mathrm{R}$ in which the IL2 domain was replaced by the corresponding loops of $\beta 3$ or $\gamma 2$ subunits of the $\mathrm{GABA}_{\mathrm{A}}$ receptor (Fig. $8 E$ ). HA-tagged $\mathrm{P} 2 \mathrm{X} 2 \Delta \mathrm{C} 36$ and P2X2 $\Delta$ C57 (lacking the C-terminal 36 and 57 amino acids, respectively) appeared to be fully functional and responded to ATP application in Xenopus oocytes (Fig. $8 A$ ) as expected by their surface expression in neuron somas and dendrites (Fig. 8B). However, because we found their axonal targeting partially impaired, their physical association with $5-\mathrm{HT}_{3 \mathrm{~A}} \mathrm{R}$-Flag was monitored by measuring Mander's M1 coefficients for their coclustering in the dendritic tree (Fig. $8 B, C$ ) and was found to be statistically not different from HA-P2X2Wt (Fig. $8 C$ ), thereby

\section{$\longleftarrow$}

couple of receptors are represented on the right panels. $\boldsymbol{B}$, Bars represent mean \pm SEM values of Mander's M1 coefficients (percentage of $5-\mathrm{HT}_{3 \mathrm{~A}} \mathrm{R}-\mathrm{HA}$ fluorescence overlapping with cotransfected receptor's fluorescence). Significant differences appeared only between interacting (P2X2) and noninteracting subunits (one-way ANOVA with Dunnett's Multiple Comparison post hoc test); $n=4-8 .{ }^{* * * *} p<0.0001$ 
A
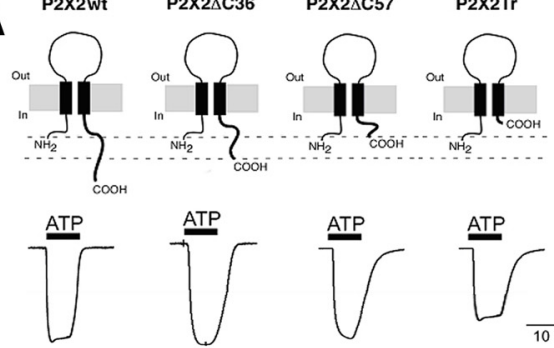

B 5-HT3A $\begin{gathered}\text { Transfected } \\ \text { receptor }\end{gathered}$
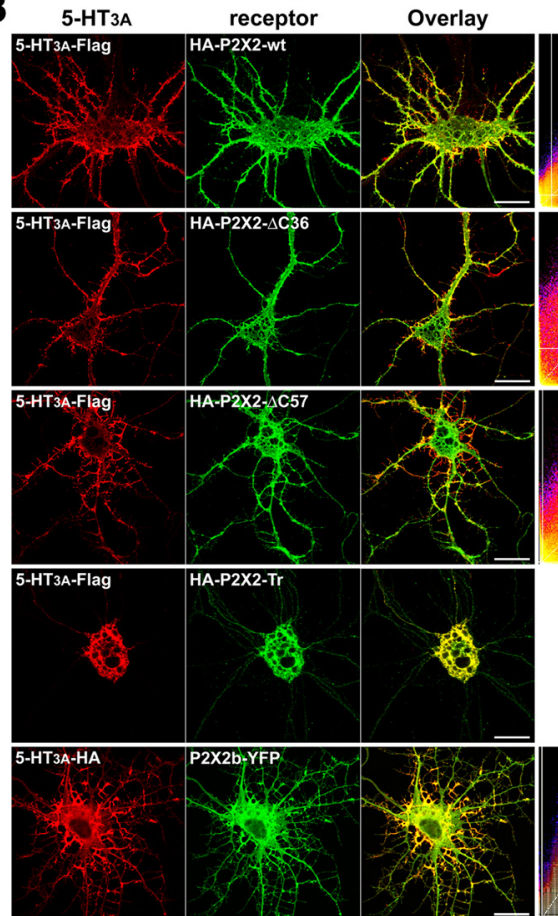

E
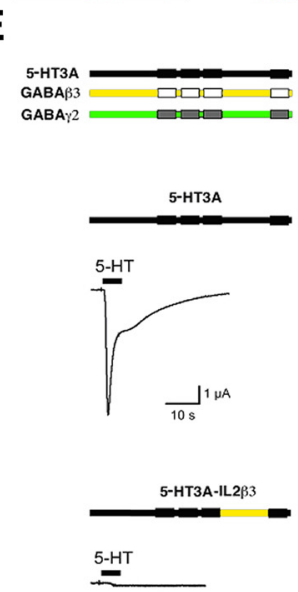

5-HT3A-IL2:

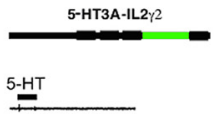

$\mathbf{F}$

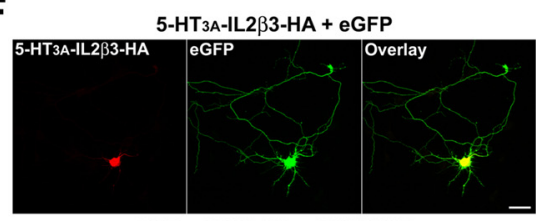

5-HT3A-IL2ß3-HA + P2X2-YFP

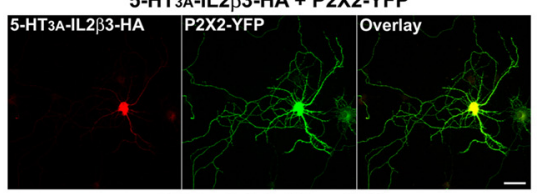

5-HT3A-IL2 2 -HA+ eGFP

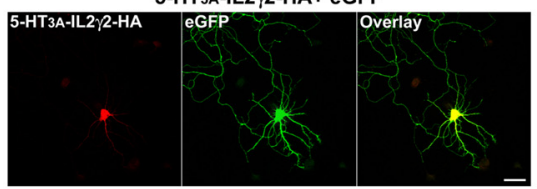

5-HT3A-IL2 $22-\mathrm{HA}+\mathrm{P} 2 \mathrm{X} 2-\mathrm{YFP}$

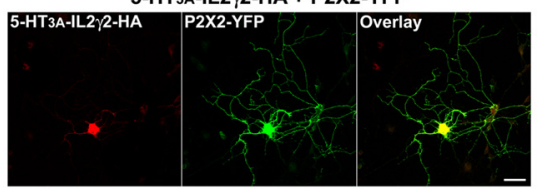

C
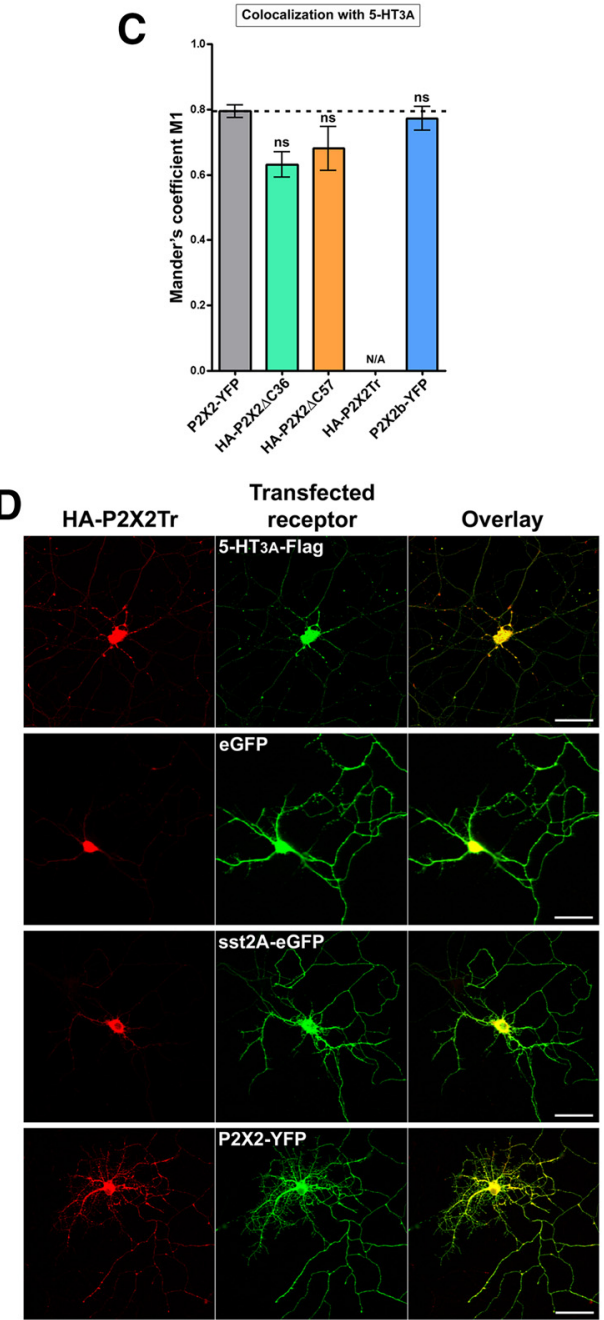

5-HT3A-IL2ß3-HA Axonal Profiles

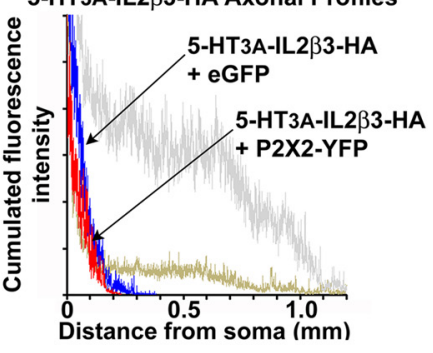

5-HT3A-IL2 $\gamma 2$-HA Axonal Profiles

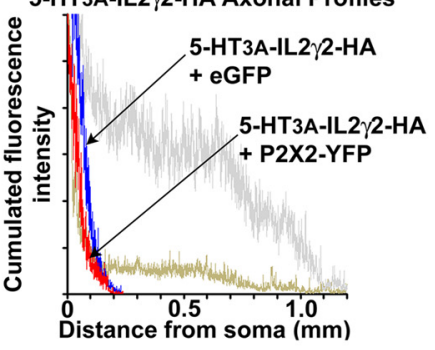

Figure 8. The physical interaction between $5-\mathrm{HT}_{3 \mathrm{~A}}$ and $\mathrm{P} 2 \mathrm{X} 2$ receptors depends on $5-\mathrm{HT}_{3 \mathrm{~A}} \mathrm{IL} 2$, but not on the $\mathrm{P} 2 \mathrm{X} 2 \mathrm{C}$-tail. $\boldsymbol{A}$, Schematic representation of $\mathrm{P} 2 \mathrm{X} 2 \mathrm{Wt}$ and the $\mathrm{C}$-terminal truncated forms: $22 X 2 \Delta C 36, P 2 X 2 \Delta C 57$, and P2X2Tr. Bottom, Current traces evoked with $100 \mu \mathrm{m}$ ATP by voltage-clamp recordings from Xenopus 00 cytes expressing each form, showing that they are all

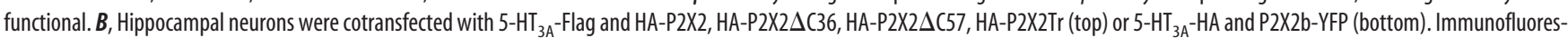
cence detection was performed at $48 \mathrm{~h}$ (red represents anti-Flag; green represents anti-HA [top]; or red represents anti-HA; green represents anti-GFP [bottom]). Right panels, Fluorograms as in Figure 7A. Scale bars, $20 \mu \mathrm{m}$. N/A, Not applicable. C, Bars indicate mean \pm SEM values of Mander's M1 coefficients. No significant differences appeared (Figure legend continues.) 

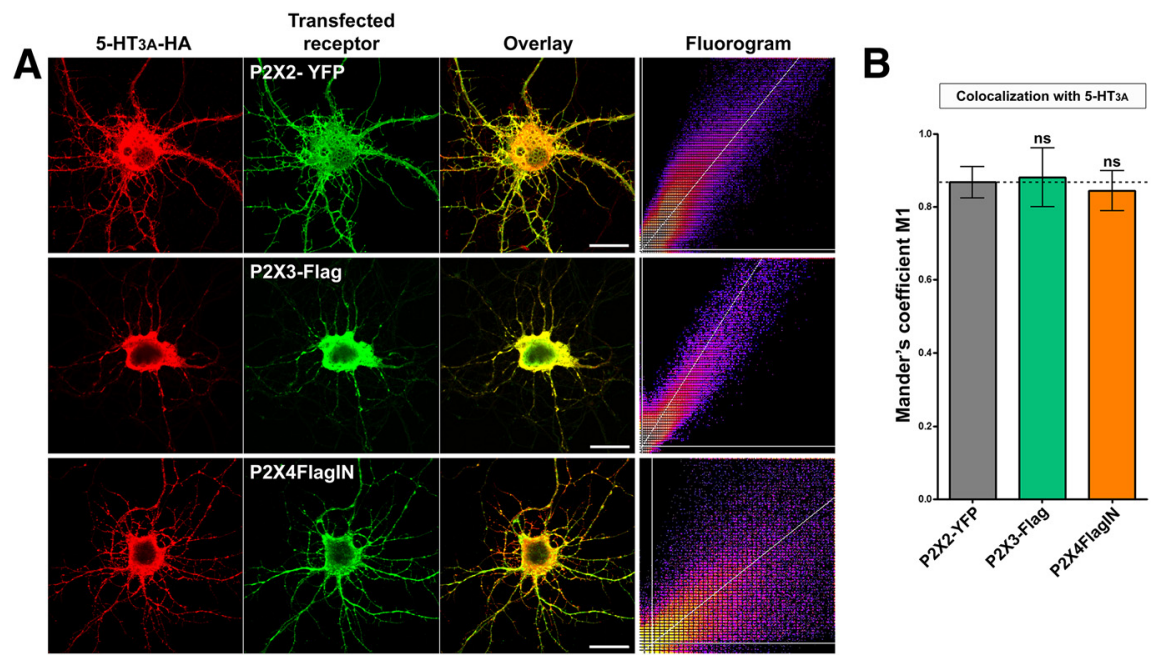

Figure 9. 5- $5 \mathrm{HT}_{3 \mathrm{~A}}$ interacts with $\mathrm{P} 2 \mathrm{X} 3 \mathrm{R}$ and $\mathrm{P} 2 \mathrm{X} 4 \mathrm{R}$. Hippocampal neurons were cotransfected at 6 DIV with $5-\mathrm{HT}_{3 \mathrm{~A}}-\mathrm{HA}$ and P2X2-YFP, P2X3-Flag, or P2X4FlagIN subunits. A, Immunofluorescence detection was performed after $48 \mathrm{~h}$ (red represents antiHA; green represents anti-eGFP or anti-Flag). Scale bars, $20 \mu \mathrm{m}$. Right panels, Fluorograms as in Figure $7 A$. $\boldsymbol{B}$, Bars indicate mean \pm SEM values of Mander's M1 coefficients. No significant differences appeared between colocalization of 5-HT 3 and P2X2Wt, P2X3, or P2X4FlagIN (one-way ANOVA with Dunnett's Multiple Comparison post hoc test); $n=4$ - 8. ns, Nonsignificant.

demonstrating that the physical association between 5- $\mathrm{HT}_{3 \mathrm{~A}}$ and $\mathrm{P} 2 \mathrm{X} 2$ receptors did not require any of the motifs present in the C-terminal tail. We also tested a naturally occurring splice variant of the $\mathrm{P} 2 \mathrm{X} 2$ receptor: the $\mathrm{P} 2 \mathrm{X} 2 \mathrm{~b}$. The $\mathrm{P} 2 \mathrm{X} 2 \mathrm{~b}$ isoform presents a 69 amino acid deletion in a sequence of the C-tail that is not present in the other subunits. This sequence contains two short hydrophobic segments highly enriched in prolines and three recognition sites for serine kinases (Simon et al., 1997). However, we did not find any differences between P2X2-YFP and P2X2bYFP, in their coclustering with $5-\mathrm{HT}_{3 \mathrm{~A}}-\mathrm{HA}$ in the dendritic trees of neurons (Fig. $8 B$, bottom, $C$ ), in their axonal distributions, or in their capability of retargeting $5-\mathrm{HT}_{3 \mathrm{~A}} \mathrm{R}$ in the axons (data not shown). Surprisingly, the complete removal of the C-terminal tail of the P2X2R had a dramatic effect on $5-\mathrm{HT}_{3 \mathrm{~A}} \mathrm{R}$ localization. $\mathrm{P} 2 \mathrm{X} 2 \mathrm{Tr}$ is a truncated form of the P2X2R lacking the 98 C-terminal amino acids, and devoid of functional interaction with $5-\mathrm{HT}_{3 \mathrm{~A}}$ receptors (Boué-Grabot et al., 2003) but in which the proximal 20 amino acids containing the YXXXK motif controlling the surface expression are conserved (Chaumont et al., 2004). Figure $8 B$ shows that this truncated form lacked completely the capability to be targeted further than $50 \mu \mathrm{m}$ from cell

\section{$\leftarrow$}

(Figure legend continued.) between colocalization of $5-\mathrm{HT}_{3 \mathrm{~A}}$ and $\mathrm{P} 2 \mathrm{X} 2 \mathrm{Wt}, \mathrm{P} 2 \mathrm{X} 2 \Delta \mathrm{C} 36$, $\mathrm{P} 2 \mathrm{X} 2 \Delta C 57$, or P2X2b (one-way ANOVA with Dunnett's Multiple Comparison post hoc test); $n=$ 4-8. ns, Nonsignificant. The measurements with P2X2Tr were not relevant because there was no dendritic expression of either subunit. $\boldsymbol{D}$, Hippocampal neurons were cotransfected at 7 DIV with HA-P2X2Tr and 5-HT 3 A-Flag, eGFP, sst2A-eGFP, or P2X2-YFP. Immunofluorescence detection was performed at $48 \mathrm{~h}$ (red represents anti-HA; green represents anti-Flag or anti-eGFP). Scale bar, $50 \mu \mathrm{m}$. E, Schematic diagrams representing $5-\mathrm{HT}_{3 \mathrm{~A}}, \mathrm{GABA}_{\mathrm{A}} \beta 3$, and $\gamma 2$ subunits, and chimeric $5-\mathrm{HT}_{3 \mathrm{~A}}$ subunits endowed with $\beta 3$ and $\gamma 2 \mathrm{IL} 2$ domains. Current traces obtained with $100 \mu \mathrm{m} 5-\mathrm{HT}$ in oocytes expressing each chimera show their nonfunctionality. $\boldsymbol{F}$, Hippocampal neurons were cotransfected at $4-5$ DIV with $5-\mathrm{HT}_{3 \mathrm{~A}} \mathrm{IL} 2 \beta 3-\mathrm{HA}$ or $5-\mathrm{HT}_{3 \mathrm{~A}} \mathrm{LL} 2 \gamma 2-\mathrm{HA}$ chimeras plus eGFP (top) or $5-\mathrm{HT}_{3 \mathrm{~A}} \mathrm{~L} 233-\mathrm{HA}$ or $5-\mathrm{HT}_{3 \mathrm{~A}} \mathrm{~L} 22 \gamma 2-\mathrm{HA}$ chimeras plus P2X2-YFP (bottom). Immunofluorescence detection of chimeras (anti-HA; red) and eGFP or P2X2-YFP (anti-eGFP; green) was performed $48 \mathrm{~h}$ after transfection. Scale bars, $50 \mu \mathrm{m}$. Graphs on the right represent cumulated fluorescence intensity profiles of $5-\mathrm{HT}_{3 \mathrm{~A}} \mathrm{IL} 2 \beta 3-\mathrm{HA}$ (top) or $5-\mathrm{HT} \mathrm{HA}_{3 \mathrm{~A}} \mathrm{~L} \gamma 2-\mathrm{HA}$ (bottom) fluorescence along the axons (longest path, $n=20$ ) for the chimeras plus eGFP (blue) or P2X2-YFP (red). Gray shades represent, for comparison, the corresponding curves obtained with 5 - $\mathrm{HT}_{3 \mathrm{~A}}$-HA (Fig. 6B). somas, indicating that the C-tail of the P2X2R contains both axonal and dendritic trafficking motifs. Interestingly, the loss of these P2X2R trafficking motifs induced a concomitant sequestration of cotransfected 5- $\mathrm{HT}_{3 \mathrm{~A}} \mathrm{R}$ within the neuron soma where both receptors colocalized completely (Fig. 8B). Further controls were designed to verify that (1) the sequestration of both receptors within the somas was not the consequence of a nonspecific blockade of the trafficking machinery by $\mathrm{P} 2 \mathrm{X} 2 \mathrm{Tr}$ overexpression and (2) the sequestration of the $5-\mathrm{HT}_{3 \mathrm{~A}} \mathrm{R}$ was specific and did not occur for a noninteracting receptor. Figure $8 D$ shows that cotransfection of HA-P2X2Tr completely impaired 5- $\mathrm{HT}_{3 \mathrm{~A}} \mathrm{R}$-Flag trafficking, even in proximal dendrites, but was without consequence on eGFP or sst2A-eGFP expression in dendrites and axons, thereby demonstrating the selectivity of this effect for $5-\mathrm{HT}_{3 \mathrm{~A}}$ receptors. Moreover, the cotransfection of P2X2R-YFP with HA$\mathrm{P} 2 \mathrm{X} 2 \mathrm{Tr}$ could rescue the latter from sequestration within cell somas (Fig. 8D), as expected if the two subunits were coassembled and if the trafficking machinery was not altered. Although these results could be interpreted either by a tight association between $5-\mathrm{HT}_{3 \mathrm{~A}}$ and $\mathrm{P} 2 \mathrm{X} 2 \mathrm{Tr}$ subunits despite the absence of the C-terminal domain, or by a complete loss of $5-\mathrm{HT}_{3 \mathrm{~A}} \mathrm{R}$ trafficking due to competition of P2X2Tr with endogenous $\mathrm{P} 2 \mathrm{X} 2 \mathrm{R}$, they clearly demonstrate the complete dependency of $5-\mathrm{HT}_{3 \mathrm{~A}} \mathrm{R}$ for their $\mathrm{P} 2 \mathrm{X} 2 \mathrm{R}$ targeting partner.

$5-\mathrm{HT}_{3 \mathrm{~A}} \mathrm{IL} 2 \beta 3-\mathrm{HA}$ and $5-\mathrm{HT}_{3 \mathrm{~A}} \mathrm{IL} 2 \gamma 2-\mathrm{HA}$ chimeras were found to be nonfunctional in Xenopus oocytes (Fig. 8E). However, this lack of response to 5-HT could largely be attributed to their lack of surface expression, as we observed in neurons (data not shown). Cotransfection of both chimeras with P2X2R-YFP in neurons at 4-5 DIV revealed that neither their surface expression nor their dendritic or axonal distributions were affected by the presence of the $\mathrm{P} 2 \mathrm{X} 2 \mathrm{R}$ within the same neurons (Fig. $8 F$ ). $\mathrm{Cu}-$ mulated fluorescence analysis in axons (Fig. $8 F$, right panels) and comparison with $5-\mathrm{HT}_{3 \mathrm{~A}} \mathrm{Wt}$ curves (in gray) showed no effect, and consequently confirmed that $5-\mathrm{HT}_{3 \mathrm{~A}}$ wild-type IL2 integrity was necessary for its physical coupling with the P2X2R.

From all these observations, we can conclude that the molecular determinants of the physical and functional couplings of $5-\mathrm{HT}_{3 \mathrm{~A}} \mathrm{R}$ and $\mathrm{P} 2 \mathrm{X} 2 \mathrm{R}$ are different. As a result, even if the functional coupling of the two receptors leading to cross-inhibition of the channels has been shown to involve a direct protein-protein contact between subunits, such a physical interaction between subunits is only one of the possible mechanisms explaining the $5-\mathrm{HT}_{3} / \mathrm{P} 2 \mathrm{X} 2$ cotrafficking, and we cannot totally exclude here the participation of a third-party scaffolding protein partner.

\section{$5-\mathrm{HT}_{3 \mathrm{~A}}$ receptors interact with other members of the P2X family}

To determine whether the receptor-receptor partnership between $5-\mathrm{HT}_{3 \mathrm{~A}} \mathrm{R}$ and $\mathrm{P} 2 \mathrm{X} 2 \mathrm{R}$ concerned other members of the P2X family, we chose the $\mathrm{P} 2 \mathrm{X} 4$ receptor because $\mathrm{P} 2 \mathrm{X} 2$ and $\mathrm{P} 2 \mathrm{X} 4$ are the two predominant purinoceptors present in brain neurons, and the P2X3 receptor because it is largely expressed in the periphery with the P2X2R to form heteromers (North, 2002). P2X3R have been de- 
scribed to undergo a rapid constitutive internalization that results in only a modest fraction being present at the plasma membrane in HEK293 cells (Vacca et al., 2009). We confirmed such a distribution in neurons cotransfected with $5-\mathrm{HT}_{3 \mathrm{~A}}-\mathrm{HA}$ and $\mathrm{P} 2 \mathrm{X} 3$-Flag. In $100 \%$ of immunopositive neurons, P2X3R were only found in proximal dendrites with a distribution typical of a predominantly intracellular localization (Fig. 9A), and the same results were obtained with P2X3YFP (data not shown). As expected from a strong interaction with $\mathrm{P} 2 \mathrm{X} 3$ subunits, $5-\mathrm{HT}_{3 \mathrm{~A}} \mathrm{R}$ were also found with the same distribution in $100 \%$ of the neurons cotransfected with both subunits. No immunolabeled axons could be detected, showing that transfected P2X3R could override the lower expression of endogenous P2X2R, with a dominant effect on $5-\mathrm{HT}_{3 \mathrm{~A}} \mathrm{R}$ distribution. Colocalization of $5-\mathrm{HT}_{3 \mathrm{~A}}$ and $\mathrm{P} 2 \mathrm{X} 3$ subunits in the proximal dendritic trees was quantified by the JACoP method (Fig. 9B), which confirmed the overlap, although the clustered component of the labels was in this case mainly intracellular. Because P2X4R also undergo a rapid constitutive internalization triggered by a YXXGL motif located in the C-terminal moiety (Royle et al., 2002), we used here P2X4FlagIN, a chimera in which the internalization motif was replaced by a Flag epitope (Jo et al., 2011). This mutant exhibits a considerable increase of surface expression and thus behaves as the $\mathrm{P} 2 \mathrm{X} 2 \mathrm{R}$ in regards to trafficking within neurons, allowing to challenge its effect on $5-\mathrm{HT}_{3 \mathrm{~A}} \mathrm{R}$ distribution without the bias of a different targeting. Cotransfection of 5- $\mathrm{HT}_{3 \mathrm{~A}} \mathrm{R}-\mathrm{HA}$ with P2X4FlagIN (Fig. 9A, bottom) revealed extensive cluster colocalization, leading to Mander's M1 coefficients similar to the ones obtained with P2X2R controls (Fig. $9 B$ ). Analysis of $5-\mathrm{HT}_{3 \mathrm{~A}} \mathrm{R}$ retargeting in axons yielded results similar to those obtained with P2X2R (data not shown). These results show that $5-\mathrm{HT}_{3 \mathrm{~A}} \mathrm{R}$ can interact with other members of the P2X family of receptors, and thereby suggest that their trafficking fate depends on the type of $\mathrm{P} 2 \mathrm{X}$ partner present in the neuron, confirming the idea that, in vivo, $5-\mathrm{HT}_{3} \mathrm{R}$ subcellular localization in neurons is phenotype dependent.

\section{Discussion}

We demonstrated here that the main occurrence determining $5-\mathrm{HT}_{3} \mathrm{R}$ subcellular localization within neurons relied on the presence of one of its functionally interacting partners: the P2X2R. We first showed that $5-\mathrm{HT}_{3} \mathrm{R}$ and $\mathrm{P} 2 \mathrm{X} 2 \mathrm{R}$ are coexpressed in the same neurons in situ, and then described a differential targeting of $5-\mathrm{HT}_{3 \mathrm{~A}} \mathrm{R}$ in a subpopulation of $\mathrm{P} 2 \mathrm{X} 2 \mathrm{R}$-expressing hippocampal neurons in culture. We then showed specific colocalization of the two receptors in surface clusters and quantitatively measured the influence of $\mathrm{P} 2 \mathrm{X} 2 \mathrm{R}$ on $5-\mathrm{HT}_{3 \mathrm{~A}} \mathrm{R}$ distribution in the distal parts of axons and dendrites in cotransfected neurons. We finally identified the molecular determinants involved in this physical interaction. Our results provide evidence of a novel pathway for receptor trafficking by means of a direct receptor-receptor functional interaction, and thereby unveil the mechanism by which $5-\mathrm{HT}_{3} \mathrm{R}$ can reach their axonal localization required for the control of neurotransmitter release (Laporte et al., 1992; Doucet et al., 2000).

\section{$\mathrm{P} 2 \mathrm{X} 2$ receptors control the subcellular localization of 5- $\mathrm{HT}_{3 \mathrm{~A}}$ receptors}

Our results are consistent with an asymmetrical dominant role of the $\mathrm{P} 2 \mathrm{X} 2 \mathrm{R}$ as a specific targeting protein partner for the $5-\mathrm{HT}_{3 \mathrm{~A}}$ homomeric receptor in neurons. Six lines of evidence support this hypothesis: (1) $5-\mathrm{HT}_{3} \mathrm{R}$ and $\mathrm{P} 2 \mathrm{X} 2 \mathrm{R}$ share a remarkably overlapping regional distribution, and we presented here evidence for their coexpression in the same neurons in myenteric ganglia (Fig. $1)$; (2) in hippocampal neurons in culture, $5-\mathrm{HT}_{3 \mathrm{~A}} \mathrm{R}$ were unable to reach axonal or dendritic distal localization, or even surface representation, in neurons devoid of endogenous P2X2R (Fig. 3); (3) inhibition of native P2X2R by RNA interference led to a concomitant inhibition of the distal neuritic localization of $5-\mathrm{HT}_{3 \mathrm{~A}} \mathrm{R}$ in the population of P2X2-expressing neurons (Fig. 4); (4) cotransfection of both receptors "boosted" the distal trafficking of 5- $\mathrm{HT}_{3 \mathrm{~A}} \mathrm{R}$ in neurites (Fig. 5) and particularly in axons (Fig. 6); (5) $5-\mathrm{HT}_{3 \mathrm{~A}} \mathrm{R}$ and $\mathrm{P} 2 \mathrm{X} 2 \mathrm{R}$ cotransfected into hippocampal neurons were found to colocalize within surface clusters (Fig. 5); and (6) when the P2X2R was replaced by a truncated mutant devoid of neuritic trafficking, the $5-\mathrm{HT}_{3 \mathrm{~A}} \mathrm{R}$ was also completely sequestrated within cell somas (Fig. 8B).

The slow onset and neuron phenotype dependency of $5-\mathrm{HT}_{3 \mathrm{~A}} \mathrm{R}$ distal trafficking in hippocampal neurons, compared with other receptors (Fig. 2), already suggested that the $5-\mathrm{HT}_{3 \mathrm{~A}} \mathrm{R}$ trafficking mechanism was not driven by relatively ubiquitous proteins expressed at early times in vitro, as it is the case for the dendritic targeting of 5- $\mathrm{HT}_{1 \mathrm{~A}} \mathrm{R}$ by Yif1B (Al Awabdh et al., 2012), but rather by the cell-dependent availability of cargo or interacting proteins expressed upon neuron differentiation. Thus, both the kinetics of onset and the phenotype dependency fitted well with a P2X2R-dependent process (Fig. 3). The "boosting" of $5-\mathrm{HT}_{3 \mathrm{~A}} \mathrm{R}$ axonal targeting by cotransfection of $\mathrm{P} 2 \mathrm{X} 2 \mathrm{R}$ at 4-5 DIV confirmed that differentiation of P2X2R-expressing neurons could be mimicked by ectopic P2X2R expression, which resulted in a shift of neurons exhibiting axonal $5-\mathrm{HT}_{3 \mathrm{~A}} \mathrm{R}$ targeting from $11 \%$ to $79 \%$ (Fig. 6). This phenomenon could not be attributed to a nonspecific driving of one protein by the other due to overexpression because it was not observed with GFP controls or when $\mathrm{P} 2 \mathrm{X} 2 \mathrm{R}$ were replaced by other receptors that were not interacting functionally with the $5-\mathrm{HT}_{3 \mathrm{~A}} \mathrm{R}$, and was asymmetrical because the subcellular distribution of $\mathrm{P} 2 \mathrm{X} 2 \mathrm{R}$ was not modified by cotransfection of $5-\mathrm{HT}_{3 \mathrm{~A}} \mathrm{R}$. Conversely, $5-\mathrm{HT}_{3 \mathrm{~A}} \mathrm{R}$ trafficking observed in the subpopulation of neurons expressing endogenous P2X2R could be inhibited either by P2X2 RNA interference (Fig. 4) or by cotransfection of a P2X2R trafficking-deficient mutant: the $\mathrm{P} 2 \mathrm{X} 2 \operatorname{Tr}$ (Fig. 8B). Interestingly, this last result could have two different interpretations: (1) P2X2Tr could have retained its capability of interaction with the $5-\mathrm{HT}_{3 \mathrm{~A}} \mathrm{R}$ and could induce a dominant sequestration of the latter in cell somas, without affecting the trafficking of other receptors (Fig. 8D); or (2) P2X2Tr could have lost its interaction with the $5-\mathrm{HT}_{3 \mathrm{~A}} \mathrm{R}$ but competed with endogenous $\mathrm{P} 2 \mathrm{X} 2 \mathrm{R}$ to override their normal trafficking by coassembly. Thus, both hypotheses led to the same conclusion: the $5-\mathrm{HT}_{3 \mathrm{~A}} \mathrm{R}$ is dependent on its $\mathrm{P} 2 \mathrm{X} 2 \mathrm{R}$ partner for trafficking. The $5-\mathrm{HT}_{3 \mathrm{~A}} \mathrm{R}$ and $\mathrm{P} 2 \mathrm{X} 2 \mathrm{R}$ physical association was further supported by the colocalization of both receptors in surface clusters along axonal and dendritic membranes, suggesting a common surface trafficking mechanism (Fig. 5). This colocalization was specific, as demonstrated by the cotransfection with other receptors noninteracting functionally with the $5-\mathrm{HT}_{3 \mathrm{~A}} \mathrm{R}$ (Fig. 7), and was robust, suggesting that the physical association between $5-\mathrm{HT}_{3 \mathrm{~A}} \mathrm{R}$ and $\mathrm{P} 2 \mathrm{X} 2$ is probably a long-lasting interaction involving a high percentage of receptors, unlike the one between $\mathrm{GABA}_{\mathrm{A}}$ and $\mathrm{P} 2 \mathrm{X} 2$ that seems more transient (Shrivastava et al., 2011) and exhibits subunit dependency (Boué-Grabot et al., 2004a).

Our results do not exclude that other proteins, not ubiquitously expressed in all neurons, could be involved in the fate of 5 - $\mathrm{HT}_{3} \mathrm{R}$ because $\sim 20 \%$ of neurons transfected by both receptors still did not address $5-\mathrm{HT}_{3 \mathrm{~A}} \mathrm{R}$ distally (Fig. 6D). For instance, RIC-3, a protein that has been shown to participate to $5-\mathrm{HT}_{3} \mathrm{R}$ and $\alpha 7 \mathrm{R}$ surface expression (Cheng et al., 2005), was found in only $17 \%$ of hippocampal neurons in culture at $18-24$ DIV and promoted the folding and the trafficking of native $\alpha 7 \mathrm{R}$ in dendrites, but not axons (Alexander et al., 2010). However, this percentage does not account for the $30 \%$ of neurons exhibiting distal 
$5-\mathrm{HT}_{3} \mathrm{R}$ targeting capacity after $7 \mathrm{DIV}$, whereas $97 \%$ of neurons expressing native $\alpha 7 \mathrm{R}$ were found immunopositive for RIC-3 (Alexander et al., 2010). This makes the participation of RIC-3 in $\mathrm{P} 2 \mathrm{X} 2 \mathrm{R}$-induced distal trafficking of $5-\mathrm{HT}_{3} \mathrm{R}$ unlikely, unless the presence of RIC-3 in neurons actually has the opposite effect and prevents $5-\mathrm{HT}_{3} \mathrm{R}$ to couple to $\mathrm{P} 2 \mathrm{X} 2 \mathrm{R}$, which would be more consistent with the preferential sequestration of $\alpha 7 \mathrm{R}$ in the dendritic endoplasmic reticulum compartment induced by the high expression of RIC-3 in neurons.

\section{The physical and functional couplings of 5- $\mathrm{HT}_{3 \mathrm{~A}}$ and $\mathrm{P} 2 \mathrm{X} 2$ receptors involve different molecular determinants}

Convergent data demonstrated that the physical coupling between P2X2R and other receptor classes is a direct protein-protein interaction involving angström scale distances consistent with dimer formation between subunits (Khakh et al., 2005). Thus, we have previously shown that the molecular determinants of the functional cross-inhibition between $5-\mathrm{HT}_{3 \mathrm{~A}}$ and $\mathrm{P} 2 \mathrm{X} 2$ receptors are located within the IL2 of the $5-\mathrm{HT}_{3 \mathrm{~A}} \mathrm{R}$ and the intracellular C-terminal tail of the P2X2R (Boué-Grabot et al., 2003). However, because competition experiments by P2X2-CT minigenes could uncouple 5- $\mathrm{HT}_{3 \mathrm{~A}}$ and $\mathrm{P} 2 \mathrm{X} 2$ functionally but not physically in Xenopus oocytes, as shown by coimmunoprecipitation, it was concluded that the $\mathrm{C}$ terminus of the P2X2R was not implicated in the formation of the $5-\mathrm{HT}_{3 \mathrm{~A}} / \mathrm{P} 2 \mathrm{X} 2$ physical complex (Boué-Grabot et al., 2003). The results obtained here confirm this hypothesis because all the C-terminal truncated forms of the P2X2R tested still colocalized with $5-\mathrm{HT}_{3 \mathrm{~A}} \mathrm{R}$ (Fig. $8 \mathrm{~B}$ ) or influenced 5- $\mathrm{HT}_{3 \mathrm{~A}} \mathrm{R}$ axonal targeting. Conversely, replacing the IL2 of the $5-\mathrm{HT}_{3 \mathrm{~A}}$ by the corresponding sequences of $\mathrm{GABA}_{\mathrm{A}} \beta 3$ or $\gamma 2$ subunits resulted in the uncoupling of both chimeras from the $\mathrm{P} 2 \mathrm{X} 2 \mathrm{R}$ and led to the independent trafficking of both receptors (Fig. $8 F$ ). This result shows that IL2 is necessary for the cotrafficking of $5-\mathrm{HT}_{3} \mathrm{R}$ and $\mathrm{P} 2 \mathrm{X} 2 \mathrm{R}$. However, its replacement, even by a functionally interacting loop as the $\beta 3$, is not sufficient to restore the physical coupling, whereas in the case of the homomeric GABAc $(\rho 1)$ receptor, partial restoration of the physical coupling could be obtained with the same strategy (Boué-Grabot et al., 2004b). From these results, we can conclude that (1) the molecular determinants of the physical and functional couplings of $5-\mathrm{HT}_{3 \mathrm{~A}} \mathrm{R}$ and $\mathrm{P} 2 \mathrm{X} 2 \mathrm{R}$ are different, and (2) the mechanisms of physical coupling between $\mathrm{P} 2 \mathrm{X} 2 \mathrm{R}$ and the other interacting 4-TMD channel receptors are probably not identical.

\section{$5-\mathrm{HT}_{3 \mathrm{~A}}$ receptors interact with other members of the P2XR family}

The results obtained with the P2X3R and the internalizationdefective mutant P2X4FlagIN (Jo et al., 2011) suggest that the $\mathrm{P} 2 \mathrm{X} 2 \mathrm{R}$ is probably not the only partner of the $5-\mathrm{HT}_{3 \mathrm{~A}} \mathrm{R}$ in vivo (Fig. 9) and that this receptor-receptor physical coupling probably results from intrinsic properties common to several P2XR. Thus, a new level of complexity in $5-\mathrm{HT}_{3} \mathrm{R}$ trafficking could be inferred, depending on the $\mathrm{P} 2 \mathrm{X}$ subunits coexpressed with the $5-\mathrm{HT}_{3} \mathrm{R}$, some of them being targeted distally and some others being internalized. Moreover, as many P2X subunits coassemble to form heterotrimers, another level of complexity might result from intermediate trafficking fates of heteromers (Saul et al., 2013). Our results also disclose a possible physiological role for the natural splice variants of $\mathrm{P} 2 \mathrm{X}$ receptors that are devoid of electrophysiological activity, as the P2X2c and P2X2d (Simon et al., 1997), as they might just be trafficking proteins for other receptors. Moreover, the existence of four additional human $5-\mathrm{HT}_{3}$ subunits that can coassemble with the $5-\mathrm{HT}_{3 \mathrm{~A}}$ (Niesler et al., 2003) and the possibility that they could all differentially interact with more than one $\mathrm{P} 2 \mathrm{X}$ subunits open an intriguing number of possible trafficking schemes.

In conclusion, we describe here that the receptor-receptor interaction between $5-\mathrm{HT}_{3}$ and $\mathrm{P} 2 \mathrm{X} 2$ receptors is not restricted to a functional coupling but extends to an intimate physical interaction that leads to a dominant influence of $\mathrm{P} 2 \mathrm{X} 2 \mathrm{R}$ on $5-\mathrm{HT}_{3} \mathrm{R}$ subcellular localization. Hence, we propose to assign, to this family of ATP receptors, a new role of trafficking partners for other classes of receptors.

\section{References}

Al Awabdh S, Miserey-Lenkei S, Bouceba T, Masson J, Kano F, MarinachPatrice C, Hamon M, Emerit MB, Darmon M (2012) A new vesicular scaffolding complex mediates the G-protein-coupled 5-HT1A receptor targeting to neuronal dendrites. J Neurosci 32:14227-14241. CrossRef Medline

Alexander JK, Sagher D, Krivoshein AV, Criado M, Jefford G, Green WN (2010) Ric-3 promotes alpha7 nicotinic receptor assembly and trafficking through the ER subcompartment of dendrites. J Neurosci 30:1011210126. CrossRef Medline

Barajas-López C, Espinosa-Luna R, Zhu Y (1998) Functional interactions between nicotinic and P2X channels in short-term cultures of guinea-pig submucosal neurons. J Physiol 513:671-683. CrossRef Medline

Barajas-López C, Montaño LM, Espinosa-Luna R (2002) Inhibitory interactions between 5-HT3 and P2X channels in submucosal neurons. Am J Physiol Gastrointest Liver Physiol 283:G1238-G1248. CrossRef Medline

Benson DL, Watkins FH, Steward O, Banker G (1994) Characterization of GABAergic neurons in hippocampal cell cultures. J Neurocytol 23: 279-295. CrossRef Medline

Bobanovic LK, Royle SJ, Murrell-Lagnado RD (2002) P2X receptor trafficking in neurons is subunit specific. J Neurosci 22:4814-4824. Medline

Bolte S, Cordelières FP (2006) A guided tour into subcellular colocalization analysis in light microscopy. J Microsc 224:213-232. CrossRef Medline

Boué-Grabot E, Archambault V, Séguéla P (2000) A protein kinase C site highly conserved in P2X subunits controls the desensitization kinetics of P2X(2) ATP-gated channels. J Biol Chem 275:10190-10195. CrossRef Medline

Boué-Grabot E, Barajas-López C, Chakfe Y, Blais D, Bélanger D, Emerit MB, Seguela P (2003) Intracellular cross talk and physical interaction between two classes of neurotransmitter-gated channels. J Neurosci 23: 1246-1253. Medline

Boué-Grabot E, Toulmé E, Emerit MB, Garret M (2004a) Subunit-specific coupling between gamma-aminobutyric acid type A and $\mathrm{P} 2 \mathrm{X} 2$ receptor channels. J Biol Chem 279:52517-52525. CrossRef Medline

Boué-Grabot E, Emerit MB, Toulmé E, Séguéla P, Garret M (2004b) Crosstalk and co-trafficking between rhol/GABA receptors and ATP-gated channels. J Biol Chem 279:6967-6975. CrossRef Medline

Boyd GW, Doward AI, Kirkness EF, Millar NS, Connolly CN (2003) Cell surface expression of 5-hydroxytryptamine type 3 receptors is controlled by an endoplasmic reticulum retention signal. J Biol Chem 278:2768127687. CrossRef Medline

Carrel D, Masson J, Al Awabdh S, Capra CB, Lenkei Z, Hamon M, Emerit MB, Darmon M (2008) Targeting of the 5-HT1A serotonin receptor to neuronal dendrites is mediated by Yif1B. J Neurosci 28:8063-8073. CrossRef Medline

Carrel D, Simon A, Emerit MB, Rivals I, Leterrier C, Biard M, Hamon M, Darmon M, Lenkei Z (2011) Axonal targeting of the 5-HT1B serotonin receptor relies on structure-specific constitutive activation. Traffic 12: 1501-1520. CrossRef Medline

Castillo M, Mulet J, Gutiérrez LM, Ortiz JA, Castelán F, Gerber S, Sala S, Sala F, Criado M (2005) Dual role of the RIC-3 protein in trafficking of serotonin and nicotinic acetylcholine receptors. J Biol Chem 280:2706227068. CrossRef Medline

Chaumont S, Jiang LH, Penna A, North RA, Rassendren F (2004) Identification of a trafficking motif involved in the stabilization and polarization of P2X receptors. J Biol Chem 279:29628-29638. CrossRef Medline

Cheng A, McDonald NA, Connolly CN (2005) Cell surface expression of 5-hydroxytryptamine type 3 receptors is promoted by RIC-3. J Biol Chem 280:22502-22507. CrossRef Medline

Collingridge GL, Olsen RW, Peters J, Spedding M (2009) A nomenclature 
for ligand-gated ion channels. Neuropharmacology 56:2-5. CrossRef Medline

Davies PA, Pistis M, Hanna MC, Peters JA, Lambert JJ, Hales TG, Kirkness EF (1999) The 5-HT3B subunit is a major determinant of serotoninreceptor function. Nature 397:359-363. CrossRef Medline

Doucet E, Miquel MC, Nosjean A, Vergé D, Hamon M, Emerit MB (2000) Immunolabeling of the rat central nervous system with antibodies partially selective of the short form of the 5-HT3 receptor. Neuroscience 95:881-892. CrossRef Medline

Doucet E, Latrémolière A, Darmon M, Hamon M, Emerit MB (2007) Immunolabelling of the 5-HT 3B receptor subunit in the central and peripheral nervous systems in rodents. Eur J Neurosci 26:355-366. CrossRef Medline

Emerit MB, Doucet E, Darmon M, Hamon M (2002) Native and cloned 5-HT(3A)(S) receptors are anchored to F-actin in clonal cells and neurons. Mol Cell Neurosci 20:110-124. CrossRef Medline

Glatzle J, Sternini C, Robin C, Zittel TT, Wong H, Reeve JR Jr, Raybould HE (2002) Expression of 5-HT3 receptors in the rat gastrointestinal tract. Gastroenterology 123:217-226. CrossRef Medline

Grailhe R, de Carvalho LP, Paas Y, Le Poupon C, Soudant M, Bregestovski P, Changeux JP, Corringer PJ (2004) Distinct subcellular targeting of fluorescent nicotinic alpha 3 beta 4 and serotoninergic 5-HT3A receptors in hippocampal neurons. Eur J Neurosci 19:855-862. CrossRef Medline

Graves AR, Moore SJ, Bloss EB, Mensh BD, Kath WL, Spruston N (2012) Hippocampal pyramidal neurons comprise two distinct cell types that are countermodulated by metabotropic receptors. Neuron 76:776-789. CrossRef Medline

Holbrook JD, Gill CH, Zebda N, Spencer JP, Leyland R, Rance KH, Trinh H, Balmer G, Kelly FM, Yusaf SP, Courtenay N, Luck J, Rhodes A, Modha S, Moore SE, Sanger GJ, Gunthorpe MJ (2009) Characterisation of 5-HT3C, 5-HT3D and 5-HT3E receptor subunits: evolution, distribution and function. J Neurochem 108:384-396. CrossRef Medline

Jensen AA, Davies PA, Bräuner-Osborne H, Krzywkowski K (2008) 3B but which $3 \mathrm{~B}$ and that's just one of the questions: the heterogeneity of human 5-HT3 receptors. Trends Pharmacol Sci 29:437-444. CrossRef Medline

Jo YH, Donier E, Martinez A, Garret M, Toulmé E, Boué-Grabot E (2011) Cross-talk between P2X4 and gamma-aminobutyric acid, type A receptors determines synaptic efficacy at a central synapse. J Biol Chem 286: 19993-20004. CrossRef Medline

Khakh BS, North RA (2012) Neuromodulation by extracellular ATP and P2X receptors in the CNS. Neuron 76:51-69. CrossRef Medline

Khakh BS, Zhou X, Sydes J, Galligan JJ, Lester HA (2000) State-dependent cross-inhibition between transmitter-gated cation channels. Nature 406: 405-410. CrossRef Medline

Khakh BS, Gittermann D, Cockayne DA, Jones A (2003) ATP modulation of excitatory synapses onto interneurons. J Neurosci 23:74267437. Medline

Khakh BS, Fisher JA, Nashmi R, Bowser DN, Lester HA (2005) An angstrom scale interaction between plasma membrane ATP-gated P2X2 and alpha4beta2 nicotinic channels measured with fluorescence resonance energy transfer and total internal reflection fluorescence microscopy. J Neurosci 25:6911-6920. CrossRef Medline

Koshimizu TA, Kretschmannova K, He ML, Ueno S, Tanoue A, Yanagihara N, Stojilkovic SS, Tsujimoto G (2006) Carboxyl-terminal splicing enhances physical interactions between the cytoplasmic tails of purinergic P2X receptors. Mol Pharmacol 69:1588-1598. CrossRef Medline

Laporte AM, Koscielniak T, Ponchant M, Vergé D, Hamon M, Gozlan H (1992) Quantitative autoradiographic mapping of 5-HT3 receptors in the rat CNS using [125I]iodo-zacopride and [3H]zacopride as radioligands. Synapse 10:271-281. CrossRef Medline

Lee S, Hjerling-Leffler J, Zagha E, Fishell G, Rudy B (2010) The largest group of superficial neocortical GABAergic interneurons expresses ionotropic serotonin receptors. J Neurosci 30:16796-16808. CrossRef Medline

Lelouvier B, Tamagno G, Kaindl AM, Roland A, Lelievre V, Le Verche V, Loudes C, Gressens P, Faivre-Baumann A, Lenkei Z, Dournaud P (2008) Dynamics of somatostatin type $2 \mathrm{~A}$ receptor cargoes in living hippocampal neurons. J Neurosci 28:4336-4349. CrossRef Medline

Maricq AV, Peterson AS, Brake AJ, Myers RM, Julius D (1991) Primary structure and functional expression of the 5HT3 receptor, a serotoningated ion channel. Science 254:432-437. CrossRef Medline

Miquel MC, Emerit MB, Nosjean A, Simon A, Rumajogee P, Brisorgueil MJ, Doucet E, Hamon M, Vergé D (2002) Differential subcellular localization of the 5-HT3-As receptor subunit in the rat central nervous system. Eur J Neurosci 15:449-457. CrossRef Medline

Morales M, Wang SD (2002) Differential composition of 5-hydroxytryptamine3 receptors synthesized in the rat CNS and peripheral nervous system. J Neurosci 22:6732-6741. Medline

Niesler B, Frank B, Kapeller J, Rappold GA (2003) Cloning, physical mapping and expression analysis of the human 5-HT3 serotonin receptor-like genes HTR3C, HTR3D and HTR3E. Gene 310:101-111. CrossRef Medline

North RA (2002) Molecular physiology of P2X receptors. Physiol Rev 82: 1013-1067. CrossRef Medline

Pougnet JT, Toulme E, Martinez A, Choquet D, Hosy E, Boué-Grabot E (2014) ATP P2X receptors downregulate AMPA receptor trafficking and postsynaptic efficacy in hippocampal neurons. Neuron 83:417-430. CrossRef Medline

Ren J, Bian X, DeVries M, Schnegelsberg B, Cockayne DA, Ford AP, Galligan JJ (2003) P2X2 subunits contribute to fast synaptic excitation in myenteric neurons of the mouse small intestine. J Physiol 552:809-821. CrossRef Medline

Richler E, Shigetomi E, Khakh BS (2011) Neuronal P2X2 receptors are mobile ATP sensors that explore the plasma membrane when activated. J Neurosci 31:16716-16730. CrossRef Medline

Royle SJ, Bobanoviæ LK, Murrell-Lagnado RD (2002) Identification of a non-canonical tyrosine-based endocytic motif in an ionotropic receptor. J Biol Chem 277:35378-35385. CrossRef Medline

Rubio ME, Soto F (2001) Distinct localization of P2X receptors at excitatory postsynaptic specializations. J Neurosci 21:641-653. Medline

Saul A, Hausmann R, Kless A, Nicke A (2013) Heteromeric assembly of P2X subunits. Front Cell Neurosci 7:250. CrossRef Medline

Shrivastava AN, Triller A, Sieghart W, Sarto-Jackson I (2011) Regulation of GABA(A) receptor dynamics by interaction with purinergic P2X(2) receptors. J Biol Chem 286:14455-14468. CrossRef Medline

Simon J, Kidd EJ, Smith FM, Chessell IP, Murrell-Lagnado R, Humphrey PP, Barnard EA (1997) Localization and functional expression of splice variants of the P2X2 receptor. Mol Pharmacol 52:237-248. CrossRef Medline

Sugita S, Shen KZ, North RA (1992) 5-Hydroxytryptamine is a fast excitatory transmitter at 5-HT3 receptors in rat amygdala. Neuron 8:199-203. CrossRef Medline

Tecott LH, Maricq AV, Julius D (1993) Nervous system distribution of the serotonin 5-HT3 receptor mRNA. Proc Natl Acad Sci U S A 90:14301434. CrossRef Medline

Vacca F, Giustizieri M, Ciotti MT, Mercuri NB, Volonté C (2009) Rapid constitutive and ligand-activated endocytic trafficking of P2X receptor. J Neurochem 109:1031-1041. CrossRef Medline

van Hooft JA, Vijverberg HP (2000) 5-HT(3) receptors and neurotransmitter release in the CNS: a nerve ending story? Trends Neurosci 23:605-610. CrossRef Medline

Vavra V, Bhattacharya A, Zemkova H (2011) Facilitation of glutamate and GABA release by P2X receptor activation in supraoptic neurons from freshly isolated rat brain slices. Neuroscience 188:1-12. CrossRef Medline

Vucurovic K, Gallopin T, Ferezou I, Rancillac A, Chameau P, van Hooft JA, Geoffroy H, Monyer H, Rossier J, Vitalis T (2010) Serotonin 3A receptor subtype as an early and protracted marker of cortical interneuron subpopulations. Cereb Cortex 20:2333-2347. CrossRef Medline

Vulchanova L, Arvidsson U, Riedl M, Wang J, Buell G, Surprenant A, North RA, Elde R (1996) Differential distribution of two ATP-gated channels (P2X receptors) determined by immunocytochemistry. Proc Natl Acad Sci U S A 93:8063-8067. CrossRef Medline

Walstab J, Hammer C, Lasitschka F, Möller D, Connolly CN, Rappold G, Brüss M, Bönisch H, Niesler B (2010) RIC-3 exclusively enhances the surface expression of human homomeric 5-hydroxytryptamine type $3 \mathrm{~A}$ (5-HT3A) receptors despite direct interactions with 5-HT3A, -C, -D, and -E subunits. J Biol Chem 285:26956-26965. CrossRef Medline 